ALARCÓN, Gilmer: "Interés público y despenalización de los delitos contra el honor

cometidos a través de la prensa. Una evaluación de la experiencia peruana"

Polit. Crim. Vol. 15, No 30 (Diciembre 2020), Art. 16, pp. 1009 - 1051

[http://politcrim.com/wp-content/uploads/2020/12/Vol15N30A16.pdf]

\title{
Interés público y despenalización de los delitos contra el honor cometidos a través de la prensa. Una evaluación de la experiencia peruana*
}

\section{Public Interest and Decriminalization of Crimes against Honour Committed Through the Press. An Evaluation of the Peruvian Experience}

\author{
Gilmer Alarcón Requejo \\ Profesor de Metodología Jurídica en la Unidad de Posgrado, Facultad de Derecho y \\ Ciencia Política, Universidad Nacional Mayor de San Marcos, Perú. \\ galarconr@unmsm.edu.pe
}

\begin{abstract}
Resumen
El presente artículo evalúa la aplicación del interés público en el razonamiento del legislador peruano para la despenalización de los delitos contra el honor. Se tomaron en cuenta elementos dogmáticos de carácter constitucional y penal sobre las disposiciones normativas que protegen el honor frente al ejercicio ilegítimo de la libertad de expresión. Este marco permitió analizar el contenido conceptual del interés público en relación con la libertad de expresión. Este es uno de los criterios más destacados para la despenalización de conductas que lesionan el honor, donde la difusión de información y opinión son de especial relevancia para el despliegue del proceso democrático y los derechos fundamentales en un Estado constitucional. En una primera etapa, los proyectos de ley evaluados denotan una adhesión débil al rol del interés público para fortalecer las premisas deliberativas del proceso democrático. Tampoco discutieron adecuadamente el contenido protegido del derecho al honor y su protección a través de vías alternativas. Estas limitaciones mejoraron en la etapa más reciente del debate, lo cual denota un mayor interés argumentativo en la aplicación del interés público como criterio normativo para fundamentar la despenalización en concordancia con los deberes de motivación de un legislador racional.
\end{abstract}

Palabras clave: Interés público, libertad de expresión, despenalización, delitos contra el honor.

\begin{abstract}
This article analyses the application of the public interest in the reasoning of the Peruvian legislator for the decriminalization of crimes against honour. Dogmatic elements of a constitutional and criminal nature were taken into account on the normative provisions that protect honour against the illegitimate exercise of freedom of expression. This framework made it possible to analyse the conceptual content of the public interest in relation to freedom of expression. This is one of the most prominent criteria for the decriminalization of conduct that damages honour, where the dissemination of information and opinion are of special relevance for the deployment of the democratic process and fundamental rights in a constitutional State. In a first stage, the bills evaluated show a weak adherence to the role of

\footnotetext{
* Este artículo es uno de los resultados del proyecto de investigación "Conflictos entre derechos fundamentales y la despenalización de los delitos cometidos a través de la prensa”, aprobado mediante Resolución $\mathrm{N}^{\circ} 041$ 2017-UJBM-R, Universidad Jaime Bausate y Meza, Lima-Perú. Actualizado hasta octubre de 2019.
} 
the public interest to strengthen the deliberative premises of the democratic process. Nor did they adequately discuss the protected content of the right to honour and its protection through alternative means. These limitations improved in the most recent stage of the debate, which denotes a greater argumentative interest in the application of the public interest as a normative criterion to base decriminalization in accordance with the motivational duties of a rational legislator.

Keywords: Public interest, freedom of expression, decriminalization, crimes against honour

\section{Introducción}

La libertad de expresión cuenta con un amplio reconocimiento en las declaraciones y pactos para la protección de los derechos humanos, que se refleja en las disposiciones normativas de rango constitucional y legal de los ordenamientos internos de aquellos países adscritos a los sistemas regionales para la protección de estos derechos. ${ }^{1}$ El correlato jurisprudencial de este fenómeno ha desarrollado los alcances y características de tal derecho fundamental.

Ya sea en la jurisprudencia de los altos tribunales internos o en la de los tribunales supranacionales, la resolución de los conflictos entre el derecho a la libertad de expresión y los derechos de la personalidad, permitió el desarrollo de reglas y estándares para su interpretación. En el ámbito de los ordenamientos internos, la protección del derecho al honor constituye uno de los límites del derecho a la libertad de expresión e información. Al respecto, destaca el análisis de los conflictos iusfundamentales entre la protección de la libertad de expresión y el derecho al honor. Se trata de un enfoque doctrinario útil para analizar las experiencias de despenalización de los delitos contra el honor cometidos a través de la prensa.

Por su parte, los postulados de teoría de la libertad preferente y los de la aplicación del test de ponderación inciden en la resolución del conflicto entre la protección de la libertad de expresión y el honor. También, permiten identificar las razones por las cuales la protección penal del honor, en los delitos cometidos a través de la prensa, no siempre satisfacen las exigencias del principio democrático, ni los de la dignidad humana. ${ }^{2} \mathrm{Al}$ respecto, la doctrina jurisprudencial norteamericana y la alemana presentan como punto en común la aplicación del criterio del interés público. Progresivamente, la Corte Interamericana de Derechos Humanos (Corte IDH) dotó de mayores alcances al interés público como criterio para la protección del derecho a la libertad de expresión. Resalta, por la incidencia de su fallo, el caso Kimel vs. Argentina, en el que determinó la responsabilidad de dicho Estado y exhortó, entre otras medidas, a reformar la legislación penal para la protección del honor. ${ }^{3}$ Esta reforma, constituye un paso relevante en la interpretación de los conflictos iusfundamentales

\footnotetext{
1 Los instrumentos internacionales que reconocen los derechos humanos conforman el bloque de constitucionalidad de los ordenamientos jurídicos de los países que los ratifican. Al respecto, cabe mencionar la advertencia formulada por Ferrajoli sobre los procesos actuales de integración jurídica cada vez más complejos por la confluencia de fuentes que se integran al ordenamiento estatal. Si bien la norma fundamental se enriquecerá a partir del desarrollo de los instrumentos internacionales y de su interpretación por los organismos que conforman los sistemas regionales, y universal de protección de los derechos humanos, se deben superar las objeciones basadas en el principio de soberanía. FERRAJOLI (2004), p. 4.

${ }^{2}$ Esta consideración toma como punto de partida el postulado humanista para la protección de la libertad de expresión que se manifiesta con mayor intensidad en situaciones relativas a la expresión de principios de moralidad política. DWORKIN (1984), p. 293 y ss.

${ }^{3}$ Corte Interamericana de Derechos Humanos, Caso Kimel vs. Argentina. Fondo, Reparaciones y Costas. Sentencia de 2 de mayo de 2008, Serie C No. 177, párr. 127 y 128 y punto resolutivo $\mathrm{n}^{\circ} 11$ de la sentencia.
} 


\section{Polít. Crim. Vol. 15, No 30 (Diciembre 2020), Art. 16, pp. 1009 - 1051 [http://politcrim.com/wp-content/uploads/2020/12/Vol15N30A16.pdf]}

entre el honor y la libertad de expresión, y acerca la discusión sobre estos delitos a la tradición norteamericana. Advertimos un mayor desarrollo del referido criterio en el caso Fontevecchia y D'Amico vs. Argentina y especialmente en el reciente fallo del caso Álvarez vs. Venezuela. Los argumentos desarrollados por la Corte IDH refuerzan este debate, el cual no es ajeno al contexto peruano.

Pese al archivamiento de las iniciativas legislativas previas sobre la despenalización de los delitos contra el honor, cometidos a través de la prensa, este debate se mantiene vigente en Perú. ${ }^{4}$ En el último período legislativo, el partido mayoritario en el Congreso no impulsó dicha agenda y mantuvo una clara línea legislativa orientada a restringir mediata o inmediatamente las libertades comunicativas. ${ }^{5}$ Esta conducta se explica, entre otros, a partir del rol que habría jugado el periodismo de investigación para dejar en evidencia la trama de corrupción entre empresarios, políticos y magistrados, a propósito de casos como los de Odebrecht, Cuellos blancos del puerto, Lava Juez. ${ }^{6}$

En el ámbito casuístico peruano, observamos una pretensión dirigida a instrumentalizar la jurisdicción para perseguir la labor periodística, a través de la interposición de querellas por delitos contra el honor. Estos procesos dan cuenta de cómo los jueces aplicaron los principios y criterios para la resolución de los conflictos entre la libertad de expresión y el honor. ${ }^{7}$ Esta línea interpretativa se tradujo en la elaboración de un precedente vinculante denominado Acuerdo Plenario $\mathrm{N}^{\mathrm{o}}$ 3-2006/CJ-116. El tratamiento jurisprudencial sobre el referido

\footnotetext{
${ }^{4}$ Campaña impulsada por la sociedad civil peruana, entre otras, por la Asociación Nacional de Periodistas del Perú (ANP), quien promueve una iniciativa para la despenalización de los delitos contra el honor desde el año 2006. En una entrevista brindada a un diario de circulación nacional en Perú, la vicepresidenta de la Federación Internacional de Periodistas (FIP), y secretaria general de la ANP, Zuliana Lainez enfatizó que los casos de persecución contra periodistas dan cuenta de un uso ilegítimo de las querellas. CAPILLO (2019), passim.

${ }^{5}$ Entre los principales proyectos legislativos que, bajo una aparente preocupación por proteger las libertades informativas, suponían una intromisión desproporcionada en distintas dimensiones del derecho a la libertad de expresión e información, tenemos: Proyecto No 233/2016-CR, presentado el 12 de septiembre de 2016; Proyecto No 1120/2016-CR, presentado el 31 de marzo de 2017; Proyecto No 3990/2018-CR, presentado el 6 de marzo del 2019; Proyecto No 4275/2018-CR, presentado el 3 de mayo del 2019. En la misma línea, pero con fundamentos materiales distintos, la mayoría parlamentaria aprobó, el 15 de junio del 2018, la Ley $\mathrm{N}^{\circ}$ 30793, que regula el gasto de publicidad del Estado Peruano y entró en vigencia el 19 de junio del 2018. Dicha norma fue declarada inconstitucional por el Tribunal Constitucional el 11 de octubre del 2018, mediante la Sentencia del Pleno Jurisdiccional recaída en los Expedientes No 0012-2018-PI/TC y 0013-2018-PI/TC. El colegiado argumentó, entre otros, que aquella norma constituía un mecanismo indirecto de censura, orientado a impedir la comunicación de circulación de ideas y opiniones. En: https://bit.ly/2rCxfB6 [visitado el 18.08.2019].

${ }^{6}$ El análisis politológico de este fenómeno señala los problemas de precariedad institucional y política, que se agudizaron en los eventos políticos suscitados a partir de la renuncia del presidente Pedro Pablo Kuczynski, en marzo del año 2018, a raíz del caso Lava Jato. Véase, PONCE (2019), pp. 341-365. A partir de las revelaciones del referido caso y del destape de una red de corrupción al interior de las principales instituciones tutelares del país, en julio del 2018, el presidente Martín Vizcarra propuso una serie de reformas a nivel constitucional para afrontar dicha crisis. Sin embargo, la mayoría en el congreso se opuso a dichas iniciativas. Posteriormente, pretendió elegir irregularmente a los nuevos miembros del Tribunal Constitucional, previa denegación de la segunda cuestión de confianza, por lo que fue disuelto el 30 de setiembre mediante Decreto Supremo de cierre del congreso, publicado en la edición extraordinaria del 30 de setiembre del 2019. En: https://bit.ly/2oO5FPS [visitado el 10.10.2019].

${ }^{7}$ Al respecto, la jurisprudencia peruana da cuenta de los siguientes casos, Caja Rural de Ahorro y Crédito de San Martín, STC Exp. No 0905-2001-AA/TC (Tribunal Constitucional del Perú 14 de Agosto de 2002); Mufarech vs. Salinas, Expediente N 668-2003-Q (20 Juzgado Penal de Lima 2004 de Noviembre de 2004); Meier vs. León, Expediente No 14156-2014 (42 Juzgado Penal de Reos Libre de Lima 3 de Mayo de 2016); García vs. Valencia, Expediente No 05730-2013 (16º Juzgado Penal de Lima 14 de Marzo de 2017); y Eguren vs. Salinas, Expediente No 4771-2018 (Juzgado Penal Unipersonal de Piura 8 de Abril de 2019).
} 
conflicto iusfundamental no tuvo un correlato equivalente en la actividad legislativa. El legislador peruano mostró interés en superar las exigencias de la racionalidad legislativa, en materia de libertad de expresión, a través de las iniciativas legislativas presentadas entre los años 2006 y 2019. Pese a la corriente para la despenalización de los delitos contra el honor, impulsada por la Comisión Interamericana de Derechos Humanos a través de la Relatoría para la Libertad de expresión, dichos proyectos no fueron aprobados.

Frente a esta experiencia, cabe preguntarse lo siguiente: ¿Cuáles son los alcances conceptuales del interés público y de su relación con el derecho a la libertad de expresión? ¿La protección del derecho al honor, a partir de tipos penales que sancionan las expresiones injuriosas de interés público, satisface las exigencias del principio de proporcionalidad? ¿El interés público en las propuestas para la despenalización de los delitos contra el honor, elaboradas por el legislador peruano, supera las exigencias de política criminal? En suma ¿Cómo se articula el interés público a la despenalización de los delitos contra el honor cometidos a través de la prensa en el marco del orden democrático?

Las discusiones sobre estas preguntas se han dado en el marco de los procesos antes mencionados, como parte de una constante reflexión doctrinaria sobre los conflictos entre el honor y la libertad de expresión en la región. No obstante, el tratamiento de los alcances conceptuales y prácticos del término interés público, en relación a la experiencia de la despenalización, no han recibido suficiente atención. Por ello, abordamos dichas cuestiones en las tres secciones que componen el presente artículo, enfocándonos en la experiencia peruana.

La primera parte aborda los tópicos conceptuales sobre interés público y su relación con la libertad de expresión. Dicho tratamiento considera el marco teórico de los conceptos jurídicos indeterminados y la lectura dicotómica que distingue la esfera pública de la privada. Al considerar las exigencias del principio democrático y las del principio de derechos humanos, los ejercicios legítimos de la libertad de expresión que afecten el derecho al honor, constituyen un conjunto de discursos que se adscriben en un ámbito de protección reforzada.

En la segunda parte, se evalúa el interés público como criterio normativo idóneo para sostener una propuesta que despenalice los delitos contra el honor cometidos a través de la prensa y como condición de precedencia a favor de la libertad de expresión. Dicha propuesta, en términos abstractos, es evaluada desde las exigencias de la dogmática penal y de la política criminal. También se da cuenta de la aplicación de este criterio en la jurisprudencia peruana constitucional y penal.

Finalmente, se analizan los proyectos legislativos $\mathrm{N}^{\circ}$ 912/2006-CR, $\mathrm{N}^{\circ} 4581-2010-\mathrm{CR}, \mathrm{N}^{\circ}$ 459-2011-CR y N $\mathrm{N}^{\circ} 4184 / 2018-\mathrm{CR}$, que contenían distintas propuestas formuladas por el legislador peruano para la despenalización de los delitos contra el honor cometidos a través de la prensa. El eje del análisis lo constituye el interés público como criterio normativo aplicado por el legislador y la incidencia de su definición previa, elaborada principalmente desde el ámbito jurisdiccional. También observamos los aportes formulados por las organizaciones de la sociedad civil y la contribución de los órganos del Sistema Interamericano de Derechos Humanos. 


\section{El interés público frente a los conflictos iusfundamentales entre la libertad de expresión y el derecho al honor}

Desarrollar los alcances del interés público como concepto jurídico indeterminado permite abordar el problema de la vaguedad de los términos y los conceptos valorativos que el legislador adopta en el desarrollo de las disposiciones jurídicas constitucionales y legales. Este marco permite relacionar el interés público y la libertad de expresión de cara al principio de legalidad.

Dado un conflicto iusfundamental entre libertad de expresión y honor, podemos afirmar que, si bien el interés público no satisface por si solo las exigencias del principio de proporcionalidad, constituye un criterio normativo válido para evaluar los discursos que ameritan una protección diferenciada. De esta manera, el interés público opera como un criterio idóneo para cuestionar aquellas normas que no satisfacen exigencias propias del principio democrático, en relación con la libertad de expresión.

\subsection{Alcances del interés público en tanto concepto jurídico indeterminado}

Abordar el interés público desde el marco de los conceptos jurídicos indeterminados exige revisar las pautas interpretativas elaboradas desde la filosofía del derecho. ${ }^{8}$ Este enfoque permite comprender sus alcances conceptuales y las consecuencias prácticas derivadas de su relación con el derecho a la libertad de expresión. La discusión de los conceptos jurídicos ya sea en sede legislativa, doctrinaria o jurisprudencial coadyuva a delimitar el contenido de los derechos fundamentales. ${ }^{9}$ Dado un conflicto iusfundamental, la actividad interpretativa es intensa y configura un debate que aborda el contenido de las normas que pueden ser indeterminadas y derrotables.

Desde la perspectiva de la indeterminación lingüística, el término interés público adolece de una considerable amplitud semántica debido la polisemia de sus componentes. Esta se manifiesta - por citar un ejemplo - en la dificultad para distinguir la finalidad de las disposiciones normativas que contienen dicho término. ${ }^{10} \mathrm{La}$ atribución de significados exige determinar aquellas situaciones de hecho que resultan comprendidas dentro del alcance de

\footnotetext{
8 Ródenas considera que los problemas de indeterminación y discrecionalidad distinguen la actividad interpretativa de la creación discrecional del derecho. El primer espacio corresponde a la actividad de los aplicadores del derecho y sólo en casos especiales, que la autora identifica como supuestos de derrotabilidad radical de las normas, se podrá justificar la discrecionalidad judicial. RÓDENAS (2012), p. 20. Confróntese, Lifante, quien considera que la conceptualización de la discrecionalidad es una actividad de desarrollo y concreción del derecho que deja en manos del operador jurídico la determinación de los medios más idóneos para alcanzar determinados fines. LIFANTE (2002), p. 424.

${ }^{9}$ Los conceptos jurídicos indeterminados constituyen un tipo específico de vaguedad característico de los términos valorativos. Califican cuestiones fácticas prescindiendo de una descripción detallada de las condiciones para su aplicación. Por ello, la aplicabilidad de estos conceptos resulta controvertida de cara a los casos concretos. Según Ródenas, el problema de vaguedad comprende dos dimensiones, una de dificultad semántica y otra de conflicto valorativo. RÓDENAS (2012), p. 30. Por su parte, Dworkin distingue los conceptos meramente vagos y los conceptos interpretativos, los cuales dan cuenta de los problemas de la polisemia y de los desacuerdos de carácter político y moral que originan los conflictos interpretativos, respectivamente. DWORKIN (1986), p. 45 y ss. Desde una perspectiva más analítica, Atienza y Ruiz Manero señalan que los denominados conceptos jurídicos indeterminados califican valorativamente una conducta, o un estado de cosas, en términos de propiedades descriptivas. Esta es la razón por la que su aplicabilidad concreta resulta controvertible en la mayoría de los casos. ATIENZA y RUIZ (2000), p. 41.

${ }^{10}$ GONZÁLEZ y VIVEROS (2000), passim; confróntese, LOVERA (2006), pp. 55-96.
} 
los términos que conforman el texto de las normas. ${ }^{11}$ Cuando el legislador emplea un concepto jurídico indeterminado, manifiesta su renuncia a describir detalladamente todas las propiedades que posee dicho concepto en la disposición normativa y toma como sustento la remisión a los acuerdos valorativos vigentes en el colectivo social. ${ }^{12}$ A través del trabajo interpretativo se pueden delimitar algunas características de estos mediante reglas aplicadas vía jurisprudencial y analizadas a nivel doctrinal.

Las críticas a la conceptualización del interés público advierten sobre los riesgos de confusión y manipulación a los que puede conducir la inclusión de una carga ideológica subyacente. ${ }^{13} \mathrm{Si}$ bien esta objeción es acertada, cuando revisamos las nociones que conforman los conceptos indeterminados, no debemos descuidar las advertencias sobre la argumentación frente al auditorio universal y al particular. ${ }^{14}$ Por ello, procuraremos definir las principales características del interés público desde las coordenadas del debate entre liberalismo y republicanismo. La primera constante que observamos en el tratamiento del interés público es la dicotomía entre lo particular y lo general, o lo individual y lo colectivo. ${ }^{15}$ A partir de ella, la distinción entre la esfera pública y privada reproduce algunas de las diferencias entre la libertad de los antiguos frente a la libertad de los modernos. ${ }^{16}$ Mientras que la tradición republicana enfatiza la importancia de los espacios públicos de deliberación, la tradición liberal resalta la importancia de la no interferencia del Estado en la esfera de libertades del individuo. ${ }^{17}$ La superación de la dicotomía radical se da gracias a la racionalidad procedimental que permite instituir un adecuado equilibrio entre dichas dimensiones. ${ }^{18}$ Sin embargo, una lectura dicotómica tradicional ha permitido distinguir el ámbito objetivo y subjetivo del interés público. El primero estaría conformado por aquellos asuntos que resultan trascendentes para la comunidad y sus integrantes. Esto equivale a las condiciones necesarias para su supervivencia y el resguardo de los medios que posibilitan la

\footnotetext{
${ }^{11}$ LAPORTA (2002), p. 140 y ss.

12 LAPORTA (2002) pp. 60 y ss., confróntese MORESO (2002), p. 106.

${ }^{13}$ LÓPEZ (2010), p. 125., confróntese, NOGUEIRA (2004), p. 155 y ss.

${ }^{14}$ La noción de auditorio que elabora Perelman y Olbrechts-Tyteca, comprende el auditorio particular y el general. Los argumentos son elaborados a partir del auditorio del que se busca lograr la adhesión. Cuanto más específicos sean los argumentos, será más difícil lograr la adhesión del auditorio universal. Esta dificultad es aún más grande, cuando la discusión comprende valores abstractos. Si en la discusión se precisa y especifica el contenido de dichos valores, la adhesión del auditorio resulta limitada. PERELMAN y OLBRECHTSTYTECA (1989), p. 132 y ss.

15 Aquí, observamos la noción aristotélica del interés público ligado al bien común por oposición al interés particular. Para el referido filósofo, el bien común es la causa final del gobierno. Asimismo, en la tradición escolástica, el bien común da cuenta de la suma de bienes individuales que trascienden su mera agregación. El bien común se trataría de aquello que es compartido en un sentido profundo y permite el desarrollo y perfeccionamiento de los miembros de una comunidad política. ARISTÓTELES (2000), passim. Desde un planteamiento que retoma la premisa aristotélica, observamos la noción de bien común expuesta por Rawls, a la cual añade el bien privado como la finalidad de una sociedad justa. RAWLS (1996), p. 19. Por su parte, Bobbio denomina la gran dicotomía o dicotomía fundamental a la tensión entre la esfera pública y la privada. BOBBIO (1998), p. 11 y ss.

${ }^{16}$ CONSTANT (2000), passim.

${ }^{17}$ La valoración de esta dimensión tiene como uno de sus hitos más relevantes el llamado a la tolerancia que formularon los filósofos de la ilustración, entre los cuales destaca John Stuart Mill, quien elaboró severas críticas a las premisas utilitaristas y abogó por una mayor protección de la individualidad. MILL (2013), passim.

18 Tanto Habermas como Rawls consideran haber superado dicha distinción a partir de un modelo de racionalidad procedimental que permite instituir un adecuado equilibrio entre ambas dimensiones. VALLESPIN (1998), pp. 9-28.
} 
convivencia de sus miembros. ${ }^{19}$ El segundo, da cuenta de los sujetos institucionales o individuales que participan activamente en el espacio público. Se trata de una distinción contingente que varía conforme a contextos y circunstancias históricas determinadas. ${ }^{20}$ Así, la distinción dicotómica entre lo público y lo privado, resulta necesaria en el plano abstracto porque facilita apreciar las dimensiones del interés público. Mientras que en el plano concreto, no es adecuado mantener una concepción excluyente entre intereses individuales y colectivos.

La tensión entre la esfera pública y la esfera privada también comprende a los actores intermedios cuya intervención permite contrarrestar posiciones que pretenden limitar los derechos individuales, empleando una noción del interés público contraria a los límites establecidos por el principio de subsidiariedad. ${ }^{21}$ A partir del surgimiento de los derechos difusos y sus respectivos mecanismos procesales se han dado pasos importantes para superar la aparente dicotomía radical entre el interés público y los intereses particulares. En este espacio intermedio observamos la diversificación de materias que no son competencia exclusiva del Estado ni dependen sólo de la voluntad del individuo. Al diversificar dichas materias, se amplía también el contenido del interés público en una dinámica que guarda relación con el reconocimiento constitucional y legal de los denominados intereses difusos y la protección de los bienes colectivos. ${ }^{22}$ Este panorama da pie a nuevos modelos epistemológicos que reelaboran el contenido del interés público incluyendo exigencias del pluralismo. ${ }^{23}$

La segunda constante en el tratamiento del interés público es la presencia de un elemento axiológico que desplaza a los intereses particulares, sin anularlos. A modo de ilustración, podemos identificar la relación entre el principio de transparencia asociado a lo público, que pese a su importancia, no puede aplicarse vaciando de contenido los derechos individuales. ${ }^{24}$

${ }^{19}$ En este sentido, Hernández considera que el interés público debe entenderse como un producto de las discusiones respecto al rol del Estado y la sociedad civil frente a las exigencias planteadas por el Estado de bienestar. HERNÁNDEZ (1997), p. 58 y ss.

${ }^{20}$ El planteamiento escéptico de la noción dicotómica del interés público, esgrimido por Buchanan, McCormick y Tollison coincide con la visión hobbesiana del interés público. Este señala que su búsqueda por parte de un agente público no se contrapone con su interés personal. En este sentido, el interés público es el resultado "de la búsqueda del interés personal dentro de un marco institucional". Este planteamiento también resalta la contingencia de la noción de interés público en función del contexto y de los imperativos sociales vigentes. BUCHANAN et al. (1984), p. 24 y ss.

${ }^{21}$ El principio de subsidiariedad, exige que las relaciones entre asociaciones superiores, inferiores e individuos de una comunidad política interactúen de tal manera que el bien común no absorba, reemplace o socave las iniciativas libres de asociaciones inferiores e individuos. En atención a este principio, el Estado no debe interferir con la autodeterminación autónoma y de libre gobierno que es una condición necesaria para la realización humana. AUDI (2004), p. 915.

22 GONZÁLES (1997), p. 453 y ss. Confróntese, SANTANA (2000), p. 37 y ss.; y CAPPELLETTI (2010), p. 47 y ss.

${ }^{23}$ Al respecto, observamos la propuesta epistemológica de la Etnografía del Interés Público centrada en el estudio de su contenido a partir de la interacción entre los intereses más generales (nivel macro) y los más específicos transmitidos por los actores de la esfera pública de debate y acción en una sociedad (nivel micro). Este es uno de los retos del constitucionalismo contemporáneo y de los distintos enfoques que buscan explicar al interés público como un proceso en permanente construcción y redefinición dinámica, necesario para responder las exigencias de la sociedad pluralista. Este método etnográfico propuesto por las corrientes antropológicas adscritas a la tradición boasiana (antropologías socioculturales públicas) busca definir el interés público a partir de dos perspectivas. La primera, centrada en los procesos políticos, mientras que la segunda se enfoca en la búsqueda de la expansión de los marcos epistemológicos y conceptuales para estudiar los procesos públicos sociales y culturales. SANDAY (2013), p. 201.

${ }^{24}$ GARZÓN (2006), p. 71 y ss. Desde el análisis de la adjudicación jurisprudencial, Covarrubias, señala que en los casos en que los derechos de acceso a la información y a la libertad de expresión entran en conflicto con 
La lectura dicotómica de la mano con el factor axiológico permite distinguir los respectivos espacios de protección y solucionar dicho conflicto valorando cada factor del caso concreto. De ahí que no es adecuado considerar a priori la prevalencia del interés público, en tanto concepto asociado a la protección de los espacios para la definición y tratamiento de lo público. Para evitar esta lectura, se debe tener en cuenta las dimensiones del contenido protegido de los derechos fundamentales.

Consideramos que la definición del interés público debe responder principalmente a los criterios adscritos a la racionalidad procedimental, dada su idoneidad para conciliar la esfera pública y la privada en procesos deliberativos concretos. En esta línea, podemos identificar las siguientes dimensiones del interés público: límite del ejercicio de los derechos fundamentales, cláusula de habilitación para el ejercicio de determinadas potestades públicas y criterio para resolver conflictos o colisiones de derechos. ${ }^{25}$

El contenido material del interés público es contingente pero posee un grado de objetividad que emana de las dinámicas de discusión e interacción permanentes entre los integrantes de una comunidad, sobre los valores que la guían y que el individuo incorpora en su conducta a partir del ejercicio de su autodeterminación. La aplicación del interés público como concepto jurídico indeterminado sólo será razonable en la medida que contemple los principios del Estado constitucional de Derecho. ${ }^{26}$ Este paradigma permite resolver las tensiones entre los derechos individuales y la inalienabilidad de las libertades básicas de los ciudadanos que conforman la esfera de la libertad pública y son parte de la soberanía. ${ }^{27} \mathrm{~A}$ partir de estas consideraciones el interés público supera las objeciones en relación a un contenido ideológico contrario al respeto de los derechos individuales.

En suma, podemos definir al interés público como un criterio normativo e interpretativo que forma parte de los conceptos jurídicos indeterminados. Incluye contenidos valorativos con capacidad para generar consensos que los integrantes de una comunidad reconocen como válidos. Asimismo, la noción dicotómica permite identificar las materias que no están incluidas en su ámbito conceptual, las cuales se adscriben al ámbito del interés privado. El interés público también presenta características de valor abstracto adscritas al ámbito de la discusión pública, y enmarcadas en el paradigma del Estado constitucional de derecho. Puede operar como regla de precedencia o como límite del ejercicio de derechos fundamentales, por ello, resulta un criterio normativo válido para cuestionar aquellas normas que no satisfacen las exigencias del principio democrático. En esta línea están comprendidos sus alcances prácticos como criterio normativo empleado por el legislador, o como criterio interpretativo aplicado por el juez.

\footnotetext{
la vida privada de los funcionarios públicos, el interés público operó como estándar prevalente respecto de los demás estándares. COVARRUBIAS (2015), pp. 217-270.

${ }^{25}$ PEÑA y ROSALES (2001), p. 495 y ss.

${ }^{26}$ Estas características dan cuenta de la carga valorativa e ideológica que permea el contenido material del interés público, la cual debe corresponderse con los parámetros interpretativos del Estado constitucional de derecho. Nino señala que las constituciones son el resultado del compromiso de ideologías e intereses contradictorios que contienen las tensiones y contradicciones de cláusulas de corte liberal en lo económico u obligaciones de corte socialista. Por ello, las indeterminaciones proveen de funcionalidad a las disposiciones constitucionales en los márgenes establecidos por el contenido ideológico imperante. NINO (1992), p. 129.

${ }^{27}$ RAWLS (1996), p. 116.
} 


\subsection{Interés público y su relación con la libertad de expresión}

A partir de su relación con el contenido protegido de la libertad de expresión, el interés público justifica aquellos discursos relativos, mediata o inmediatamente, a los procesos de participación y discusión en el marco de la democracia deliberativa. ${ }^{28}$ El fundamento de dicha relación reside en el principio democrático y en el de dignidad humana. De ahí que para participar en dichos procesos, los miembros de la comunidad organizada jurídicamente deben ser reconocidos como sujetos de derecho e iguales en dignidad. Su participación óptima sólo será posible si cuentan con el mayor flujo de información que les permita intervenir eficazmente en la discusión pública.

La protección del debate que trasciende la esfera de lo privado pone en relieve los procesos de conformación y transformación de la opinión pública, por ello tiene una importancia capital en los sistemas democráticos contemporáneos. ${ }^{29}$ El ideal de la democracia deliberativa trae como consecuencia la necesidad de proteger adecuadamente los procesos de conformación de los discursos de interés público. ${ }^{30}$ Esta observación coincide con el planteamiento de la Relatoría para la Libertad de Expresión de la Comisión Interamericana de Derechos Humanos (Relatoría), que sitúa el énfasis en el análisis del contenido del discurso. Dicho enfoque justifica la pertinencia de una tipificación de los discursos en función de su contenido. Con ello sustenta la necesidad de una protección reforzada para aquellos discursos referidos al ejercicio de otros derechos y al fortalecimiento del sistema democrático. ${ }^{31}$ La elaboración de una tipología de discursos, para determinar el grado de protección que les corresponde en función de su contenido, denota un esfuerzo por sistematizar las principales características descriptivas de la jurisprudencia de la Corte $\mathrm{IDH}^{32}$

El trabajo analítico de la Relatoría, denota una especial preocupación por la formulación de reglas que permitan resolver los conflictos entre el derecho a la libertad de expresión y el derecho al honor. Entre ellas, resalta el interés público que opera como estándar normativo idóneo para constituir una regla que permita resolver dichos conflictos a través de la subsunción. ${ }^{33}$ Este proceso es tributario de las tradiciones con mayor influencia en la

\footnotetext{
${ }^{28}$ NINO (2003), p. 193 y ss.

${ }^{29}$ En relación a la evolución de la opinión pública, Habermas considera que es una pieza clave en el proceso de transformación del Estado liberal de derecho al Estado social. Dicha transformación se refleja en el ideal participativo de la democracia que permite la conformación de una ciudadanía comprometida con aquellos asuntos que trascienden la esfera de lo privado y afectan a toda la comunidad. HABERMAS (1981), p. 248 y ss.

${ }^{30} \mathrm{Al}$ respecto, Charney destaca la importancia de una protección efectiva de estos discursos, por ello cuestiona los alcances de las normas penales que protegen los derechos de la personalidad, en tanto limiten desproporcionadamente la libertad de expresión. CHARNEY (2016), p. 178 y ss.

${ }^{31}$ Este tipo de discursos poseen una incidencia directa respecto de los valores democráticos, la organización institucional del Estado y la vida social. Su importancia se aprecia a partir de su rol respecto de la formación de la opinión pública, por ende, la necesidad que tiene el ciudadano de conocer la información más relevante sobre los asuntos de la vida pública y aquellos temas que afecten a la comunidad. Estos discursos comprenden: a) discurso político y sobre asuntos de interés público, b) discurso sobre funcionarios públicos en ejercicio de sus funciones y sobre candidatos a ocupar cargos públicos, y c) discursos que expresan elementos de la identidad o la dignidad personales. RELATORÍA, ESPECIAL PARA LA LIBERTAD DE EXPRESIÓN DE LA COMISIÓN INTERAMERICANA DE DERECHOS HUMANOS (2009), p. 11 y ss.

32 CORTE INTERNAMERICANA DE DERECHOS HUMANOS, Caso Herrera Ulloa vs. Costa Rica. Serie C, No. 107, 2 de julio de 2004, párr. 23, voto concurrente del juez Sergio García; Caso Ricardo Canese vs. Paraguay Serie C, No. 111, 31 de agosto de 2004, párr. 98; y Caso Fontevecchia y D'Amico vs. Argentina. Serie C, No. 177, 29 de noviembre de 2011, párr. 59.

${ }^{33}$ MENDOZA (2007), p. 93 y ss.
} 
interpretación de dichos conflictos, la norteamericana y la alemana. La tradición norteamericana se caracteriza por enfatizar, preferentemente, la importancia del principio democrático a partir de una interpretación jurisprudencial de la Primera Enmienda. ${ }^{34} \mathrm{La}$ síntesis del tratamiento de las normas relativas a las injurias, en relación al criterio de interés público, se observa en el paradigmático caso The New York Times Co. v. Sullivan. ${ }^{35}$ La Corte Suprema de los Estados Unidos destacó que un requisito indispensable para un debate robusto residía en el activo control que la prensa ejerce sobre el gobierno y los funcionarios públicos. De esta manera, las expresiones relativas a las funciones de una autoridad son discursos que coadyuvan a la fiscalización del ejercicio del poder, por lo que no deberían ser inhibidos mediante normas que la limiten. ${ }^{36}$

Por su parte, el razonamiento en la tradición alemana se orienta preferentemente por las exigencias del principio de la dignidad humana. Así, el caso Lüth puso en relieve la indeterminación de las reglas del derecho civil frente a la libertad de expresión. ${ }^{37}$ En este caso, el Tribunal Constitucional Federal de Alemania sentó las bases para la aplicación del test de ponderación. Argumentó que si bien la libertad de expresión amerita protección, esta debía retroceder si afectaba intereses dignos de protección de más alto rango. ${ }^{38} \mathrm{Si}$ bien reconoce la importancia de la libertad de expresión para el sistema democrático, no asume que este derecho posea una jerarquía que lo sitúe siempre por encima de los demás derechos, en especial, cuando existe una afectación a la dignidad humana.

Un elemento común de ambas tradiciones jurídicas y sus respectivos paradigmas interpretativos reside en el reconocimiento y la consolidación del interés público. Este criterio constituye un punto de partida para evaluar el discurso y determinar si constituye un ejercicio legítimo del derecho a la libertad de expresión o no. Ello configura una garantía para la protección reforzada de la libertad de expresión frente a los derechos de la personalidad. También es posible identificar un conjunto de estándares adicionales para la solución de la colisión entre los derechos a la libertad de expresión y el honor. Un sector de la doctrina los identifica como límites internos de la libertad de expresión. ${ }^{39}$ La crítica a esta sistematización señala que los estándares que delimitan el contenido del derecho a la libertad de expresión no constituyen límites internos, sino más bien reglas de precedencia, a través

\footnotetext{
${ }^{34}$ Las líneas interpretativas de la Corte Suprema de los Estados Unidos de Norteamérica, variaron en función a la preponderancia de la tendencia conservadora o progresista entre sus miembros. Así doctrinas como la de la censura previa, es un producto clásico de la Corte Warren, lo que se aprecia con mayor claridad en casos como New York Times v. Sullivan. Por otro lado, la tendencia conservadora interpretó restrictivamente la libertad de expresión, relativizando su protección y fundamentando la importancia de estándares como el peligro o riesgo inminente, cuando de por medio se discutía la protección de otros bienes tales como la seguridad nacional. FISS (2004), passim. Confróntese, ARIAS (2018), passim.

35 A partir de la acción de injurias presentada por el referido comisionado del Estado de Alabama contra el citado medio de la prensa escrita, la Corte Suprema de los Estados Unidos estableció que las normas relativas a las injurias de dicho Estado, eran contrarias a la Primera Enmienda. BERTONI (2000), p. 129 y ss. Confróntese, DE PABLO (2018), p. 99 y ss.

${ }^{36}$ Esta interpretación se remite a las tesis de Meiklejohn quien considera que la primera enmienda otorga una protección absoluta a todos los discursos políticos. Posteriormente este tratamiento se vio reforzado a partir de los debates en torno a la quema de banderas, Caso United States vs. Eichman, 110 S. Ct. 2404 (1990). En dicha ocasión, la Corte Suprema de los Estados Unidos reafirmó que dichas conductas eran actos de expresión política que ameritaba protección. FISS (2004), p. 23 y s.

37 SCHWABE (2009), pp. 202 y ss.

${ }^{38}$ MENDOZA (2007), p. 146.

${ }^{39}$ Aba elabora una sistematización de los límites de la libertad de expresión que los distingue entre internos y externos. Dado un conflicto iusfundamental, la pretensión permisiva del derecho a la libertad de expresión, colisiona con la pretensión prohibitiva del derecho al honor. ABA (1999), p. 78.
} 
de las cuales se evalúa el contenido mismo del derecho en relación con otro derecho intervenido. ${ }^{40}$

La estructura del conflicto entre libertad de expresión y honor exige un límite respecto de la relativización del ámbito de protección de estos derechos. Este ejercicio excluye los supuestos que no revistan significancia. ${ }^{41}$ Dicha operación facilita la identificación de variables más importantes que, además, se manifiestan constantemente en los casos concretos. Este es el procedimiento racional mediante el cual se deduce que el interés público opera como regla de precedencia. ${ }^{42} \mathrm{Al}$ abordar este criterio como una regla de precedencia, se obtiene una categoría analítica útil a efectos de evaluar las colisiones entre la libertad de expresión y el honor.

La influencia de las tradiciones jurisprudenciales norteamericana y alemana se aprecia también en los casos resueltos por la Corte IDH sobre libertad de expresión. Al respecto, destacan las sentencias de los casos Herrera Ulloa vs. Costa Rica ${ }^{43}$, Kimel vs. Argentina ${ }^{44}$ y Olmedo Bustos vs. Chile ${ }^{45}$, en los que el elemento principal para determinar la legitimidad del discurso consiste en precisar si su contenido resulta de interés público. A partir de dicha experiencia, la Relatoría elaboró la clasificación de los discursos en función de su contenido. La clasificación de los discursos especialmente protegidos resalta la importancia del interés público como estándar normativo que permite diferenciar los discursos que ameritan protección reforzada.

En el caso peruano advertimos que la aplicación del interés público, como criterio para resolver los conflictos entre el derecho al honor y el derecho a la libertad de expresión, presenta diferencias entre la sede constitucional y la ordinaria. En la interpretación del juez constitucional peruano el interés público operó como regla de precedencia, con una marcada influencia de la tesis de la posición preferente, en una primera etapa. ${ }^{46}$ Posteriormente, se observa un mayor desarrollo de los argumentos del principio de dignidad humana y la aplicación de la ponderación. ${ }^{47}$ Por su parte, la jurisdicción ordinaria no incorporó al mismo ritmo dichas construcciones doctrinarias. Una línea sostenida de su interpretación hasta mediados de la década de 1990 revelaba una aplicación formal que privilegiaba el derecho

\footnotetext{
${ }^{40}$ MENDOZA (2007), p. 413. Confróntese, URÍAS (2019), passim.

${ }^{41}$ MENDOZA (2007), p. 69 y ss.

${ }^{42}$ El interés público operaría junto a la ausencia de excesos en las expresiones, ya que la afectación de la dignidad humana delimita el ejercicio de la libertad de expresión en sentido amplio. En cuanto a la libertad de expresión, la doctrina considera al interés público, la exigencia de veracidad y la ausencia de real malicia como límites internos del acto comunicativo, para evaluar si constituye una manifestación legítima de la libertad de expresión. REBOLLO (1992), passim. Confróntese, MARCIANI (2004), p. 117.; REVENGA (2008), passim; DE PABLO (2018), p. 316.

${ }^{43}$ CORTE INTERNAMERICANA, Caso Herrera Ulloa vs. Costa Rica. párr. 127.

${ }^{44}$ CORTE INTERNAMERICANA, Caso Kimel vs. Argentina, párr. 57 y 87.

${ }^{45}$ CORTE INTERNAMERICANA, Caso Olmedo Bustos y otros vs. Chile. Serie C, No 73, s.1. : Corte Interamericana de Derechos Humanos, 5 de febrero de 2001, párr. 61.

${ }^{46}$ Esta línea de razonamiento se aprecia, entre otras, en las siguientes sentencias del Tribunal Constitucional del Perú: Caso Caja Rural de Ahorro y Crédito de San Martín, STC Exp. No 0905-2001-AA/TC, párrafos 6 y 7.

47 Orientación advertida en el Caso Gálvez Berrio, STC Exp. № 4099-2005-AA/TC, párrafos 5 y 6; Caso Lamadrid Ubillús, STC Exp. No 03079-2014-PA/TC, párrafos 29 y s.
} 
al honor. ${ }^{48}$ Esta tendencia cambió progresivamente a partir del año 2000, dada la incidencia de los fallos del Tribunal Constitucional del Perú y de la Corte IDH. ${ }^{49}$

Los argumentos de casos emblemáticos tales como León vs. Meier o García vs. Valencia, dan cuenta de una aplicación del criterio del interés público más elaborada ${ }^{50}$ Este cambio cualitativo se explica, en parte, gracias a la aplicación del precedente vinculante emitido en el año 2006 por el Pleno Jurisdiccional de las Salas Penales Permanente y Transitorias de la Corte Suprema de Justicia. ${ }^{51}$ Sin embargo, el Acuerdo Plenario No 3-2006/CJ-116 limitó el tratamiento del referido criterio a la diferenciación entre la esfera pública y privada de las personas, es decir se limitó a la dimensión subjetiva, dejando de lado la dimensión institucional. Aun así, significó un importante avance en la resolución de conflictos entre el honor y el derecho a la libertad de expresión en la judicatura peruana.

El tratamiento jurisprudencial y doctrinario, en el conflicto entre el derecho a la libertad de expresión y el derecho al honor, dota de contenido al interés público. También le otorga suficiente lógica interna y externa para operar como una regla de precedencia que permite identificar, prioritariamente, los discursos relevantes para el debate público. En resumen, permite configurar una categoría conceptual válida para justificar la necesidad de una protección reforzada de discursos sobre asuntos de relevancia pública, aplicable en las propuestas para la reforma de la tipificación de los delitos contra el honor.

\section{La aplicación del criterio interés público en la despenalización de los delitos contra el honor cometidos a través de la prensa}

Desde la dogmática penal es posible advertir que la complejidad del bien jurídico honor dificulta la interpretación de las normas penales para su protección. Por su parte, el análisis a partir de la perspectiva político criminal nos lleva a considerar que la despenalización de los delitos contra el honor, cometidos a través de la prensa, es una discusión necesaria. Ambas perspectivas coinciden en las ventajas de la protección civil del honor, en relación a la actividad probatoria y a la valoración del daño para determinar la indemnización en el marco de la responsabilidad civil extracontractual. ${ }^{52}$

\footnotetext{
${ }^{48}$ A partir del estudio de juicios contra periodistas comprendidos entre los años 1969 y 1999, Ugaz sostiene que el ejercicio judicial denotaba una opción dogmática a favor de la teoría de la exclusión. Ello llevaba a los jueces, salvo contadas excepciones, a optar preferentemente por la protección del honor. UGAZ (1999), p. 171.

${ }^{49}$ Este cambio cualitativo se aprecia a partir del diagnóstico elaborado por la Defensoría del Pueblo en el Informe Defensorial Número 48 del año 2000. Entre sus recomendaciones, señaló la importancia de incorporar el desarrollo del derecho internacional de los derechos humanos en la resolución de casos relativos a la libertad de expresión e información. DEFENSORÍA DEL PUEBLO (2000), p. 223 y ss. Posteriormente, en el año 2014, en el marco del balance de las actuaciones defensoriales, y a partir de su reconocida defensa y promoción de los derechos fundamentales, Abad señala entre los logros de dicha entidad, haber coadyuvado a la progresiva incorporación de los estándares convencionales para la protección del derecho a la libertad de expresión e información. ABAD (2014), p. 128.

${ }^{50}$ Estos casos denotan una mayor argumentación en relación a los criterios para la resolución del conflicto entre el derecho a la libertad de expresión e información y el derecho al honor. En el caso Meier vs. León (Expediente $\mathrm{N}^{\mathrm{o}}$ 14156-2014) observamos mayores alcances en relación a la noción de personaje de interés público en el que se subsumían los hechos de la querella. En el segundo caso, García vs. Valencia (Expediente No 05730-2013) destaca la aplicación de argumentos adscritos a la tesis de la posición preferente, dado que el querellante fue presidente de la república y debía mantener un margen de tolerancia más alto a la crítica.

${ }^{51}$ En relación al Acuerdo Plenario $\mathrm{N}^{\circ}$ 3-2006/CJ-116, observamos consecuencias prácticas positivas para la resolución de casos que denotaban represalias contra periodistas a partir de la interposición de querellas, tal como se registró en el caso Orellana. UGAZ (2016), pp. 217 y ss.

${ }^{52}$ Sobre las ventajas que ofrece la vía civil y los medios alternativos a la pena para reparar el honor, véase RIVERO (2008), passim; Confróntese, BUOMPADRE (2010), p. 183 y ss.; DE PABLO (2018), pp. 82 y ss.
} 
Estas discusiones brindan un marco de análisis necesario para conciliar las exigencias del principio democrático y las del principio de dignidad, a partir del cual evaluaremos la protección penal del honor a través del test de ponderación. Para ello, elaboraremos una norma hipotética que excluye los supuestos de hecho relativos a los discursos especialmente protegidos de interés público, conforme a los elementos de la teoría del delito. Se incluirán las exigencias de racionalidad que debe caracterizar al Derecho Penal, frente a los principales cuestionamientos formulados a la actividad legislativa. ${ }^{53}$ También se toma en cuenta el imperativo constitucional que debe observar la aplicación del ius puniendi en materia de interpretación y argumentación. En este sentido, se busca armonizar el ejercicio de los derechos fundamentales al evaluar la proporcionalidad de la tipificación penal de los ilícitos contra el honor. ${ }^{54}$

\subsection{Discusiones en torno al contenido protegido del bien jurídico honor}

El honor como objeto de tutela es uno de los bienes jurídicos más sutiles y complejos de abordar en el Derecho Penal. ${ }^{55} \mathrm{Al}$ respecto, la dogmática penal ha desarrollado dos líneas teóricas principales en relación a la delimitación de su contenido protegido, la concepción fáctica y la normativa. En primer lugar, la perspectiva fáctica se fundamenta en cuestiones de hecho que distinguen el ámbito subjetivo y objetivo del honor. El ámbito subjetivo parte de un dato psicológico y se traduce en la valoración personal que el sujeto tiene de sí mismo, aproximándose a la noción de autoestima. En el ámbito objetivo, la apreciación se basa en un presupuesto sociológico construido a partir de la percepción que tienen los demás miembros de la comunidad respecto del individuo. Aquí, observamos la noción de reputación social. La principal observación a la teoría fáctica señala que la protección jurídica del honor subjetivo estaría sujeta a la discrecionalidad de su titular. Sólo la persona afectada determinaría desde un plano estrictamente subjetivo, si su honor ha sido vulnerado o no. ${ }^{56}$ En cuanto a la noción objetiva del honor, la crítica señala que la consecuencia de dicho razonamiento es contraria al principio de igualdad, ya que condiciona la tutela penal al reconocimiento social y al prestigio de la persona. ${ }^{57}$

En segundo lugar, la perspectiva normativa del honor, parte del principio de la dignidad humana y del reconocimiento que recibe en los cuerpos normativos supranacionales. ${ }^{58}$ En esta concepción el desarrollo del honor presenta tres variantes. En la primera, observamos una relación de identidad entre el contenido protegido del honor y la dignidad humana. ${ }^{59}$ En

\footnotetext{
${ }^{53}$ En palabras de Nieto, estos son recursos efectivos para combatir el populismo penal y otras manifestaciones de la crisis de racionalidad y legitimidad del Derecho Penal. NIETO (2016), p. 409.

${ }^{54}$ LANDA (2018), p. 40 y ss.

${ }^{55}$ LAURENZO (2002), p. 14.

${ }^{56}$ PEÑA (2015), p. 102.

57 Estas deficiencias han sido advertidas en la doctrina hispana por: BAJO (1982), p. 124; QUINTANO (1972), p. 1152; LAURENZO (2002), p. 16.

${ }^{58}$ El contenido constitucionalmente protegido del derecho al honor, se encuentra establecida en el artículo 11 de la Convención Americana sobre Derechos Humanos, así como en el artículo 17 del Pacto Internacional de Derechos Civiles y Políticos.

${ }^{59}$ Muñoz precisa: "Dos son los elementos que determinan el concepto de honor: objetivamente: la fama o reputación social; subjetivamente, la propia estima. Ambos ingredientes son tenidos en cuenta, pero junto a estos ingredientes fundamentales en la delimitación del concepto de honor, este concepto se potencia hoy en día al equipararse con el de la dignidad humana, entendiéndose como un derecho fundamental que se reconoce a toda persona por el hecho de serlo, independientemente de su nacionalidad, sexo, religión, etc.” MUÑOZ (2001), p. 269. Por su parte, Carmona argumenta: "La noción de honor debía ajustarse al modelo constitucional
} 
la segunda, un sector de la doctrina el contenido protegido del honor no se corresponde con la dignidad humana, ya que esta es un atributo inalienable de las personas por el sólo hecho de serlo. ${ }^{60}$ En la tercera, apreciamos que el tratamiento del honor no sólo es una manifestación directa del principio de la dignidad humana, sino también del libre desarrollo de la personalidad. ${ }^{61}$

Observamos que la perspectiva normativa y la fáctica han contribuido a delimitar el contenido protegido del derecho al honor. La perspectiva normativa permitió enriquecer el contenido protegido del honor a partir de la inclusión del principio de la dignidad y del derecho al libre desarrollo de la personalidad. En el caso de la perspectiva fáctica, pese a las objeciones formuladas por su incongruencia con el principio de igualdad y dignidad humana, la terminología empleada en la dogmática penal, conserva la distinción entre las dimensiones objetiva y subjetiva del honor. Este manejo permite identificar los elementos objetivos del tipo para evaluar la lesión de este bien jurídico. ${ }^{62}$

La postura intermedia o mixta, recoge los aportes señalados en relación a los elementos fácticos y al núcleo del honor. De esta manera, se logra graduar el alcance concreto del bien jurídico. ${ }^{63}$ Esta postura también da cuenta de la integración entre el valor interno del sujeto y la pretensión de respeto que le permite desarrollarse en una comunidad. ${ }^{64}$ Esta concepción responde mejor a las exigencias del principio de legalidad porque no depende de consideraciones meramente subjetivas en torno a una conducta lesiva, sino de la legítima pretensión de no ser denigrado o desacreditado. Asimismo, se valorará la adecuación de la conducta de la persona a las normas vigentes.

La distinción entre la dimensión subjetiva y objetiva del honor, también brinda el sustrato para abordar el contenido de dicho bien jurídico en el proceso subsuntivo. Al momento de subsumir el hecho en el tipo, es posible valorar el contenido de las imputaciones contra la persona, teniendo en cuenta si la descripción negativa de su conducta guarda relación con los hechos. De esta manera, se dejan de lado variables como la posición social o la fortuna y se observa la protección del núcleo del bien jurídico honor.

La postura mixta que distingue el ámbito objetivo y subjetivo del honor, permite observar una esfera de protección que comprende la autopercepción de valía personal del individuo en constante relación con el ámbito objetivo de la conducta del sujeto. Así, el plano subjetivo se proyecta e incluye en el conjunto de relaciones intersubjetivas en las que la conducta del individuo es valorada por los demás integrantes de la comunidad. Como resultado de ambos

\footnotetext{
en el que predomina su sentido interno ideal e inteligible equivalente a dignidad y respeto humano." CARMONA (1996), p 461.

60 "Tampoco el honor puede ser sinónimo de dignidad, puesto que este es un atributo de toda persona por el sólo hecho de serlo y no depende de enjuiciamientos de terceros.” QUERALT (1996), p. 223.

61 "El derecho al honor entronca así de modo directo con el libre desarrollo de la personalidad, concretándose en un espacio de libertad que posibilita al individuo ejercitar sus propias opciones sin perder la autoestima ni el aprecio de la comunidad, o si se prefiere, en una pretensión de respeto que corresponde a toda persona por su condición de tal con independencia de su mayor o menor grado de seguimiento de un determinado código ético, moral o, incluso jurídico.” LAURENZO (2002), p. 32.

${ }^{62} \mathrm{Al}$ respecto, Laurenzo formula una crítica contra la manifestación de esta concepción en la terminología empleada por las posiciones normativas, que les lleva a distinguir el honor "real" del "merecido". Distinciones que tiene importantes consecuencias de cara a la regulación de la exeptio veritatis. LAURENZO (2002), p. 17 y ss.

${ }^{63}$ LAURENZO (2002), p. 29.

${ }^{64}$ PEREGRIN (2000), p. 83.
} 


\section{Polít. Crim. Vol. 15, No 30 (Diciembre 2020), Art. 16, pp. 1009 - 1051 [http://politcrim.com/wp-content/uploads/2020/12/Vol15N30A16.pdf]}

procesos, podemos distinguir la honra, reputación, crédito o fama, en tanto nociones de base objetiva; y el honor como noción de base subjetiva, relativo al sentimiento de valía personal del individuo. Estas consideraciones no pueden desligarse del factor histórico y cultural imperante, razón por la cual el honor resulta un bien jurídico contingente, circunstancial y relativo. ${ }^{65}$

Sin dejar de lado las consideraciones señaladas en torno a los ámbitos de protección del honor, es importante tener en cuenta el alcance conceptual de los términos empleados en los distintos dispositivos normativos para la protección de este bien jurídico. Honra y reputación aluden a las dimensiones subjetiva y objetiva del honor, respectivamente. ${ }^{66}$ A partir dicha distinción, es posible diferenciar dos grandes grupos en relación a la tipificación de las conductas lesivas de este bien jurídico. Por un lado, están aquellos ordenamientos que diferencian dos tipos en función a la afectación de la dimensión objetiva y subjetiva del honor, denominado sistema bipartito. ${ }^{67}$ Por el otro, tenemos el sistema tripartito que consagra tres tipos, resaltando como conductas agravadas aquellas en las que la intervención de un medio de comunicación conlleva la mayor difusión del acto comunicativo cuestionado. ${ }^{68}$

La regulación peruana de los ilícitos contra el honor, aplica el tratamiento tripartito. Distingue los tipos penales de injuria, calumnia y difamación. ${ }^{69}$ La estructura típica del primero descansa en la dimensión subjetiva, mientras que en el caso de los otros dos tipos, opera la dimensión objetiva. Dicha distinción también tiene un correlato en la interpretación del Tribunal Constitucional peruano ${ }^{70}$, cuyo tratamiento fue recogido en el Acuerdo Plenario No 3-2006/CJ-116, que revisaremos más adelante.

${ }^{65}$ Confróntese con BERDUGO (2000), p. 121; MAIZA (1995), pp. 191-209; PITT-RIVERS (1999), p. 235 y ss.; y DE PABLO (2014), passim.

${ }^{66}$ Esta distinción es importante porque los tipos penales para la protección del honor en la mayoría de los ordenamientos jurídicos se diferencian a partir de la dimensión objetiva o subjetiva de dicho bien jurídico. Sin embargo, Charney considera que expresiones como honor y honra se emplean como sinónimos ya que en algunos ejercicios analíticos la distinción entre dichos términos es innecesaria. CHARNEY (2016), p. 181.

${ }^{67}$ En el grupo del sistema bipartito se puede distinguir la injuria como el tipo básico de imputación y la calumnia como tipo agravado. En este sistema de clasificación se encuentra la regulación para los delitos contra el honor de España, Argentina, Chile y Colombia, entre otros.

${ }^{68}$ Entre los países que optaron por la clasificación tripartita, se encuentran: Alemania, Brasil, Bolivia y Perú, entre otros.

${ }^{69}$ Artículos 130, 131 y 132 del Código Penal del Perú, aprobado mediante Decreto Legislativo № 635.

Artículo 130: Injuria

El que ofende o ultraja a una persona con palabras, gestos o vías de hecho, será reprimido con prestación de servicio comunitario de diez a cuarenta jornadas o con sesenta a noventa días-multa.

Artículo 131: Calumnia

El que atribuye falsamente a otro un delito, será reprimido con noventa a ciento veinte días-multa.

Artículo 132: Difamación

El que, ante varias personas, reunidas o separadas, pero de manera que pueda difundirse la noticia, atribuye a una persona, un hecho, una cualidad o una conducta que pueda perjudicar su honor o reputación, será reprimido con pena privativa de libertad no mayor de dos años y con treinta a ciento veinte días-multa.

Si la difamación se refiere al hecho previsto en el artículo $131^{\circ}$, la pena será privativa de libertad no menor de uno ni mayor de dos años y con noventa a ciento veinte días-multa.

Si el delito se comete por medio del libro, la prensa u otro medio de comunicación social, la pena será privativa de libertad no menor de uno ni mayor de tres años y de ciento veinte a trescientos sesentaicinco días-multa.

${ }^{70}$ Observamos una mejora en el desarrollo del contenido protegido del honor, por el intérprete peruano. $\mathrm{Al}$ respecto, véase: Caso Caja Rural de Ahorro y Crédito de San Martín, STC Exp. № 0905-2001-AA/TC, párr. 15; Caso Gálvez Berrio, STC Exp. No 04099-2005-AA/TC, párr. 3 y s.; Caso Lima Airport Partners, STC Exp. No 4371-2012-PA/TC, voto singular del magistrado Ramos Núñez y de la magistrada Ledesma Narváez, párr. 14 y s.; y Caso Alejandro Lamadrid, STC Exp. Nº3079-2014-PA/TC, párr. 29 y s. 


\subsection{Consideraciones de política criminal}

Parte de las discusiones contemporáneas sobre el rol del Derecho Penal abordan los problemas que afectan su racionalidad. Entre ellos tenemos la pérdida de la calidad de la ley, que se manifiesta en fenómenos como la legislación simbólica o la falta de calidad en la formulación de las leyes, las cuales afectan al valor de la seguridad jurídica. ${ }^{71}$ Esta problemática coincide con el cuestionamiento a la soberanía de los Estados en el marco de la globalización jurídica. ${ }^{72}$ Frente a ello, el legislador debe reinterpretar el principio de legalidad y reserva de ley, incorporando las exigencias de los instrumentos internacionales reconocidos en sus respectivos ordenamientos jurídicos.

Una respuesta a estos fenómenos se encuentra en el mecanismo de control constitucional de las leyes penales, en el que destaca la aplicación del principio de proporcionalidad ${ }^{73}$ al que se suman las exigencias de la democracia deliberativa. ${ }^{74}$ Partiendo de estas premisas, y del contenido protegido del derecho a la libertad de expresión, así como el del honor, resulta necesario evaluar las normas penales para la protección del honor, a nivel descriptivo y prescriptivo.

En el plano descriptivo, se advierte una incidencia permanente del Sistema Interamericano de Derechos Humanos y de organizaciones no gubernamentales, sobre la importancia del rol de la prensa como mecanismo de control democrático y la incidencia del marco de la protección de la libertad de expresión, para el fortalecimiento del debate público. Al respecto, se observa una notoria preocupación por los episodios de violencia y persecución contra periodistas. ${ }^{75}$ Una modalidad de persecución se manifiesta en las demandas contra periodistas formuladas por funcionarios públicos que emplean los tipos penales comunes para la protección del honor. Este fenómeno no es reciente y denota que, pese a la derogación del delito de desacato en la mayoría de ordenamientos jurídicos de América Latina ${ }^{76}$ y al consenso sobre la importancia de los discursos de interés público, los funcionarios públicos procuran evitar la difusión de hechos noticiosos invocando la aplicación de los tipos penales

\footnotetext{
${ }^{71} \mathrm{Al}$ respecto, la crisis de la racionalidad del Derecho penal ha sido desarrollada ampliamente en la literatura norteamericana en autores como Garland y Stunz. Asimismo, fenómenos como la sobre-criminalización son abordados desde la crítica y justificación del Derecho penal. NIETO (2016), p. 407. Confróntese, DÍEZ (2003), passim.

${ }^{72}$ LANDA (2010), pp. 7-33.

73 ALEXY (2007), pp. 111 y s.

74 NIETO (2016), p. 411.

${ }^{75}$ A la par de las recomendaciones de la Relatoría para la libertad de expresión de la Comisión Interamericana, el Relator Especial sobre la promoción y protección del derecho a la libertad de opinión y expresión de las Naciones Unidas, Frank La Rue, consideró preocupante que se continúen utilizando las leyes penales contra periodistas y medios de comunicación para reprimir la información que no consideran convenientes a sus intereses. LA RUE (2012), p. 15. Confróntese, COMITÉ PARA LA PROTECCIÓN DE LOS PERIODISTAS CPJ (2015), passim.

${ }^{76}$ Desde la década de los noventas, la Comisión Interamericana advirtió del uso arbitrario de normas destinadas a establecer una protección especial para el honor de los funcionarios públicos en el desempeño de su actividad. Asimismo, en el ámbito contencioso, dicha institución conoció la solución amistosa del caso Horacio Verbitsky vs. Argentina, por expresiones injuriosas contra un juez de la Corte Suprema de dicho país. En el procedimiento ante el órgano supranacional, el Estado argentino se comprometió a retirar el delito de desacato de su legislación. COMISIÓN INTERAMERICANA DE DERECHOS HUMANOS. Informe $\mathrm{N}^{\circ}$ 22/94. Caso 11.012. Argentina. Solución Amistosa. 20 de septiembre de 1994, párr. 22. En ese sentido, el 3 de junio de 1993, mediante Ley $\mathrm{N}^{\circ} 24198$, se derogaron los artículos 244 del Código Penal y el artículo 6 de la Ley $\mathrm{N}^{\circ}$ 13985. Posteriormente, el delito de desacato fue despenalizado en los siguientes países: Paraguay (1998), Costa Rica (2002), Perú (2003), El Salvador (2004), Honduras (2004), Panamá (2004), Chile (2005), Guatemala (2006), Uruguay (2009) y Bolivia (2012).
} 


\section{Polít. Crim. Vol. 15, No 30 (Diciembre 2020), Art. 16, pp. 1009 - 1051 [http://politcrim.com/wp-content/uploads/2020/12/Vol15N30A16.pdf]}

comunes para la protección del honor. Esta situación da cuenta de cómo operan los rezagos del delito de desacato en los tipos penales vigentes para la protección del honor.

El bajo número de querellas ofrece argumentos a quienes consideran que, dadas las coincidencias de las disposiciones normativas para la protección del honor con los denominados delitos de bagatela, este bien jurídico no necesitaría de protección penal, por lo que deberían derogarse. ${ }^{77}$ ¿Se trata acaso de un tipo simbólico retributivo que cumple una función general de la pena? Desde una perspectiva cuantitativa, el bajo número de acciones penales, resultaría un indicador del desuso de este tipo penal, si no fuera que al ser empleado por un funcionario público genera un efecto contrario a las exigencias del principio democrático ${ }^{78}$ En el caso peruano, según los reportes de la Oficina de Derechos Humanos del Periodista de la Asociación Nacional de Periodistas del Perú, el número de querellas contra periodistas ha oscilado entre 10 en el año 2014 y 37 en el año $2017 .{ }^{79}$ Esta tendencia coincide con las advertencias sobre la instrumentalización de las disposiciones penales para la protección del honor. Asumir una perspectiva meramente cuantitativa, no da cuenta del impacto negativo que la persecución penal de periodistas y comunicadores tiene para el debate público, conocido como efecto inhibidor o chilling effect.

En el plano prescriptivo las experiencias de despenalización y descriminalización no han estado exentas de posteriores problemas en la aplicación de las normas reformadas. Al respecto, la experiencia argentina permite ilustrar las limitaciones en la determinación de la indemnización o de la reparación civil, ya que una suma exorbitante, tiene un efecto inhibidor equiparable a la sanción penal. ${ }^{80} \mathrm{Al}$ someter las consideraciones descriptivas y prescriptivas desde el ángulo de la política criminal, podemos distinguir las diferentes posturas en relación a la despenalización de los delitos contra el honor cometidos a través de la prensa, a nivel formal, material y pragmático.

En el plano formal, se esgrimen razones preventivas generales y especiales para mantener la protección del honor en el ámbito penal. La prevención general consiste en evitar que el honor sea estimado en términos puramente económicos. Una valoración patrimonialista del honor constituiría un incentivo perverso para los medios de comunicación y comunicadores en general. ${ }^{81}$ Estos evaluarían la difusión de hechos noticiosos sin observar un debido ejercicio de la libertad de expresión, teniendo como principal parámetro la obtención de una ganancia al margen de la indemnización. En relación a la función de prevención especial, la posición contraria a la despenalización, indica que la imposición excepcional de penas privativas de la libertad, fomenta la observancia de la norma para la protección del honor, por parte de individuos que anteriormente han sido sancionados por la comisión de dichos delitos. $^{82}$

\footnotetext{
77 VÁSQUEZ (2016), passim.

78 Al respecto, Roxin advierte sobre las dificultades para delimitar el desvalor de resultado frente a estas lesiones. Ante lo cual, la teoría de los delitos de bagatela desarrolla la justificación de la impunidad. ROXIN (1997), p. 297.

${ }^{79}$ En la clasificación elaborada por dicha institución, el rubro "amenazas judiciales" comprende las querellas por calumnia y difamación, las cuales pasaron de 15 en el año 2014, a 10 en el año 2015 y llegando a 27 en el año 2016 y 37 en el año 2017. OFICINA DE LOS DERECHOS HUMANOS DEL PERIODISTA DE LA ASOCIACIÓN NACIONAL DE PERIODISTAS DEL PERÚ, "Informes estadísticos correspondientes a los años 2015, 2016, 2017', Lima.

${ }^{80}$ CORTE INTERNAMERICANA, Caso Fontevecchia y D'Amico vs. Argentina, párr. 111.

${ }^{81}$ VILLAVICENCIO (2017), p. 492.

${ }^{82}$ PEÑA (2015), p. 320.
} 
Respecto de la visión economicista del honor, es necesario diferenciar las afectaciones en el plano objetivo y subjetivo, conforme la distinción dogmática de las dimensiones del honor. Cuando nos encontramos frente a un supuesto de afectación, en términos objetivos, una consecuencia de este hecho puede significar la afectación del patrimonio de la persona. Ante este supuesto, debe determinarse una indemnización proporcional al daño. En el plano subjetivo, cabe preguntarse por los criterios para estimar una suma que repare el daño moral, dado el margen de discrecionalidad otorgado a los jueces. ${ }^{83}$ Hasta este punto, son válidas las observaciones formuladas desde una perspectiva de prevención general. Sin embargo, bajo la misma lógica, un tratamiento del honor que privilegia la persecución penal de periodistas o comunicadores, tampoco demuestra ser un medio que repare adecuadamente el honor.

Si asumiésemos que la mejor forma de resarcir las afectaciones al honor consiste en determinar, fehacientemente, la falsedad de los hechos difundidos, encontraríamos importantes límites a nivel normativo. La mayoría de ordenamientos jurídicos restringen la aplicación de la exceptio veritatis, en lugar de promover una interpretación amplia de la misma. ${ }^{84}$ Además, tratándose de personajes públicos en general, y de funcionaros públicos en particular, la reparación del honor más efectiva se lograría a través de una mayor promoción del derecho de rectificación.

Este es el sentido del último proyecto para la despenalización de los delitos contra el honor, cometidos a través de la prensa, presentado ante el congreso peruano. ${ }^{85}$ Dicho proyecto contenía una fórmula legal que resalta la importancia del ejercicio de la rectificación y propone un conjunto de procedimientos pre-judiciales — similares a la conciliación - para operativizarlo. Es decir, busca que a través de mecanismos de comunicación y difusión, similares o equivalentes, la persona o el medio de comunicación corrija la información difundida, en caso se determine que ésta no se ajusta a los estándares del ejercicio legítimo del derecho a la libertad de expresión. Con lo que traslada al ámbito civil la determinación de la indemnización por daños contra el honor. Este también fue el tenor del anuncio más reciente sobre la reforma de estos ilícitos en Honduras. ${ }^{86}$

A nivel material, el argumento más importante en contra de la despenalización consiste en señalar el riesgo que supone instrumentalizar la dignidad humana y propiciar una fundamentación utilitarista de los derechos fundamentales. ${ }^{87}$ Lo cual se concretaría si optáramos por una preferencia automática del derecho a la libertad de expresión e información, abandonando la ponderación caso por caso. El razonamiento judicial de la Corte IDH da cuenta de la incorporación de razones materiales adscritas al principio democrático y al principio de dignidad humana ${ }^{88}$ El efecto de irradiación de este desarrollo se observa en la jurisprudencia ordinaria, constitucional y convencional, así como en los procesos de reforma respecto de los delitos contra el honor cometidos a través de la prensa.

\footnotetext{
${ }^{83}$ BOIX et al. (2013), p. 68 y ss.; confróntese, VISINTINI (2015), p. 37 y ss.

${ }^{84}$ ITURRALDE (2011), pp. 43 y ss.; confróntese, CHARNEY (2016), passim.

${ }^{85}$ Proyecto No 4184/2018-CR, presentado el 10 de abril de 2019 por los representantes parlamentarios de la Bancada Liberal. Expediente parlamentario virtual en: https://bit.ly/2qiooUm [visitado el 20.07.2019].

${ }^{86}$ En el marco de la reforma del nuevo Código Penal, el presidente del Congreso Nacional, Mauricio Oliva anunció su decisión de trasladar los ilícitos contra el honor al ámbito civil, el 29 de agosto del 2019. En: https://bit.ly/2n4mBRJ [visitado el 10.09.2019].

${ }^{87}$ MARCIANI (2004), p. 453.

88 RELATORÍA ESPECIAL PARA LA LIBERTAD DE EXPRESIÓN DE LA COMISIÓN INTERAMERICANA DE DERECHOS HUMANOS (2016), passim.
} 
A nivel pragmático, advertimos algunas preocupaciones del sector que no comparte los planteamientos de la despenalización de los delitos contra el honor cometidos a través de la prensa. Señalan la posibilidad de que al amparo de un supuesto ejercicio legítimo de derecho u oficio, se escuden campañas de desprestigio contra personajes públicos a través de la difusión de noticias falsas. ${ }^{89} \mathrm{Al}$ respecto cabe elaborar un paralelo con el criterio adoptado por los relatores especiales para la libertad de expresión en relación a las noticias falsas (fake news).${ }^{90}$ Lejos de aconsejar que el Estado regule o prohíba la circulación de información, señalaron el riesgo de que bajo la consigna de "proteger el derecho a recibir información verdadera" éste suprima la libre circulación de ideas y el disenso". ${ }^{91}$

El núcleo en común que presenta la penalización de los discursos relativos a asuntos de interés público que pueden afectar el honor de funcionarios, y la difusión de noticias falsas a través de los medios de comunicación masiva, reside en la relevancia pública de sus contenidos y en la exigencia de veracidad. De ahí que la presunción de protección reforzada no es suficiente en estos supuestos, sino la operación de los otros criterios para evaluar la legitimidad del ejercicio de la libertad de expresión. En relación a los ilícitos contra el honor relativos a personajes de interés público, cabe añadir que así como estos suscitan la atención de los medios y pueden ser difamados con facilidad, también tienen mayor acceso a los medios para realizar sus descargos y continuar con el debate público. Se trata de un recurso al que no accede el común de los ciudadanos. ${ }^{92}$

Respecto a la difusión de noticias falsas, la responsabilidad deóntica de los profesionales de la información debe intensificar su tarea de verificación de datos y contrastación de fuentes. En efecto, los ilícitos contra el honor y la propagación de noticias falsas tienen impactos negativos en los procesos de deliberación pública. Se trata de fenómenos distintos, pero con dimensiones comunes. Si bien los problemas del segundo reciben cada vez más atención por parte de la academia, coincidimos con la posición expresada por los relatores. Esta posición recoge los postulados de la tesis de la posición preferente, ya que la regulación estatal puede devenir en ejercicios desproporcionados contra la libertad de expresión. Los casos relativos a los delitos contra el honor que han llegado a la Corte IDH ilustran este problema. En esta línea, consideramos que la forma más eficaz de contrarrestar los efectos de ambos fenómenos es intensificar la práctica de la rectificación y de la verificación de datos, respectivamente..$^{93}$

\footnotetext{
${ }^{89}$ PEÑA (2015), p. 145.

${ }^{90}$ Se trata de un fenómeno que, de manera similar a los clásicos mecanismos de censura, atacan los procesos de deliberación sobre asuntos de interés público. Particularmente enfocados en los procesos democráticos y la difusión de información no contrastada. Al respecto, Botero documenta algunos casos observados en América Latina, especialmente en los procesos electorales de México, Brasil y Colombia. Estado de derecho, deliberación y posverdad en América Latina, en: https://bit.ly/2NctGtC [visitado el 11.09.2019].

91 Declaración Conjunta Sobre Libertad de Expresión y "Noticias Falsas" ("Fake News"), Desinformación y Propaganda, emitida el 3 de marzo del 2017 por expertos en materia de libertad de expresión de la Organización de las Naciones Unidas (ONU), la Organización de los Estados Americanos (OEA) y la Comisión Africana de Derechos Humanos y de los Pueblos (CADHP). En: https://bit.ly/2P1cg2I [visitado el 11.09.2019].

92 Este fue uno de los principales argumentos en el debate peruano sobre la derogación del delito de desacato. Partiendo de dicha premisa, la protección reforzada del honor de los funcionarios públicos era contraria a los lineamientos señalados por la Comisión Interamericana de los Derechos Humanos y además era contraria a la tendencia para la descriminalización de dicho tipo penal en las normas sustantivas penales de España (1995) o Colombia (2000). Comisión de Justicia del Congreso de la República del Perú. "Dictamen de la Comisión de Justicia recaído en los Proyectos de Ley 938/2001-CR, 1052/2001-CR, 1685/2001-CR, y otros, que proponen la derogación del artículo $374^{\circ}$ del Código Penal", Lima, 10 de Octubre de 2002.

${ }^{93}$ Estas consideraciones han sido materia de discusión durante la elaboración de la Carta Mundial de Ética para Periodistas, adoptada en el $30^{\circ}$ Congreso Mundial de la Federación Internacional de Periodistas, en Túnez el 12 de junio de 2019. Véase los artículos 6 y 10. En: https://bit.ly/2WPLOHV [visitado el 08.19.2019].
} 
Las razones a favor y en contra de la despenalización de los delitos contra el honor, cometidos a través de la prensa, presentan argumentos importantes que encuentran respuesta en la discusión de sus respectivos presupuestos fácticos y normativos. A partir del consenso jurisprudencial en relación a la protección diferenciada de los discursos y los alcances del criterio interés público, podemos distinguir un conjunto específico de presupuestos referidos a los funcionarios públicos. ${ }^{94}$ En él, uno de los principales elementos que sostienen la discusión dogmático penal para la despenalización de los referidos tipos penales, reside en una protección del honor que, en los hechos, es una protección reforzada. En este sentido, advertimos importantes semejanzas con los argumentos empleados en la derogación del delito de desacato. La aplicación del interés público como criterio normativo, permitió sustentar dicha reforma al colocar al funcionario en el mismo espacio que el ciudadano común, frente a la difusión de información potencialmente lesiva para el bien jurídico honor. Ello fue posible gracias al consenso alcanzado para excluir los discursos relativos al interés público del ámbito penal.

\subsection{Aplicación del test de ponderación a la norma penal para la protección del honor en función al criterio interés público}

Cuando un comunicador es denunciado debido a la difusión de un discurso de interés público que lesiona el derecho al honor, convergen dos intervenciones intensas en el ámbito de protección del derecho al honor y en el del derecho a la libertad de expresión e información. Para analizar este conflicto iusfundamental es conveniente aplicar el test de ponderación. Dicha estructura permite revisar los argumentos ofrecidos frente a este supuesto de hecho genérico.

El supuesto de hecho base está conformado por aquellos discursos de interés público, específicamente los referidos a la actividad de los funcionarios públicos. Si bien la protección del honor es un derecho que protege a todas las personas, el tratamiento de dichos discursos merece especial atención porque, prima facie, se configura una situación que privilegia la protección de la libertad de expresión. Este tratamiento es el resultado de la interpretación jurisprudencial sostenida en relación al rol de fiscalización que desempeña la prensa en torno al ejercicio del poder. ${ }^{95}$ Dicho conjunto comprende la vigilancia de la actuación de los funcionarios públicos y el manejo de los temas que comprometen a la comunidad. Se trata de una dimensión común con la tesis de la posición preferente.

La posición preferente de la libertad de expresión no deriva de una jerarquización arbitraria de los derechos fundamentales. Por el contrario, refleja la valoración de dicho derecho en tanto garantía institucional básica para el sistema democrático. En consecuencia, la presunción a favor de la libertad de expresión resulta razonable. ${ }^{96} \mathrm{Al}$ respecto, Fiss remarca

\footnotetext{
94 Se trata de personas que ejercen poder y manejan recursos públicos, con lo que el deber de fiscalización sobre ellos no debe ser restringido sino potenciado. RELATORÍA (2009), p. 11 y s.

95 Esta interpretación es tributaria de la primera enmienda de la Constitución de los Estados Unidos. En la misma línea se observa la interpretación en relación a una protección relativa del honor en el caso de los funcionarios públicos. Se trata de un tratamiento que denota elementos de la posición preferente derivada del balancing test. FISS (1999), p. 71.

${ }^{96}$ Las principales manifestaciones de la posición preferente a favor de la libertad de expresión son: a) Inversión de la carga de la prueba; b) Intolerancia de la legislación vaga e imprecisa que incremente el margen discrecional para la actuación del gobierno; c) Rechazo de normas que incluyan mayores cargas formales y procesales; d) Exigencia al gobierno para que emplee todos aquellos medios que considere necesarios para
} 


\section{Polít. Crim. Vol. 15, No 30 (Diciembre 2020), Art. 16, pp. 1009 - 1051 [http://politcrim.com/wp-content/uploads/2020/12/Vol15N30A16.pdf]}

la importancia del caso The New York Times vs. Sullivan, al enfatizar la necesidad de promover un debate desinhibido, vigoroso y abierto. Condición que no se condice con la pretensión del funcionario público para que se le indemnice ante la difusión de información de interés público. Por su parte, el Tribunal Constitucional Federal Alemán, empleó el criterio de interés público partiendo de presupuestos similares a los de la posición preferente en el caso denominado "Demócrata por obligación" (BVerfGE 82). ${ }^{97}$ Ambos tribunales coincidieron en señalar que dada una crítica pública hacia funcionarios o políticos en ejercicio, no se podía alegar una afectación al honor, porque en dicho contexto las fórmulas polémicas y exageradas debían ser toleradas.

Los discursos referidos a funcionarios públicos, resaltan la necesidad de proteger adecuadamente los procesos de conformación del discurso político. ${ }^{98}$ Son una clara manifestación del interés público y permiten formular una norma hipotética en la que se excluyen los supuestos de hecho relativos a este discurso. Sobre la base de la estructura del delito de injuria, correspondiente al sistema bipartito, es posible formular una proposición normativa que contemple la protección del bien jurídico honor y excluya los supuestos que comprendan a los discursos de interés público, en los siguientes términos:

$\mathrm{N}_{1}$ : Constituyen delito todos los actos comunicativos que lesionen el derecho al honor e': Se excluyen los discursos referidos a asuntos de interés público

En sede de tipicidad se mantienen algunas características del tipo objetivo penal base de los delitos contra el honor. El sujeto activo puede ser cualquier persona. Al excluir del ámbito de la tipicidad, los actos comunicativos relativos a asuntos de interés público, no se opera en razón de las personas, sino en razón de las características objetivas de la conducta típica. Esta operación es el resultado de la suficiencia normativa del interés público, la cual se expresa como regla de precedencia, producto del umbral de protección del derecho a la libertad de expresión. En esta sede también se debe evaluar la veracidad de los hechos difundidos. Esta exigencia se verá satisfecha con un ejercicio diligente de la referida libertad. 99 En este sentido, si la difusión de información inexacta lesiona el honor pero el comunicador actuó con la debida diligencia, estaremos frente a un supuesto de atipicidad subjetiva.

Excluir los discursos de interés público del ámbito de tipicidad de los delitos contra el honor, se basa en el criterio de la adecuación social. Según este criterio, aquellas actividades y conductas lesivas, toleradas por su utilidad social, son socialmente adecuadas, por lo tanto lícitas. ${ }^{100}$ De esta manera se restringe el alcance literal de los tipos al excluir los comportamientos socialmente adecuados. Conviene precisar que el criterio de interés público no opera sobre la totalidad de las conductas lesivas del honor, sino sólo sobre aquellas que además de revestir relevancia para la discusión de asuntos de la res pública,

\footnotetext{
lograr sus objetivos, siempre que no afecten la libertad de expresión y e) Interpretar restrictivamente todas aquellas normas que afecten la libertad de expresión. MARCIANI (2004), p. 95.

${ }^{97}$ SCHWABE (2009), p. 224 y s.

98 Al respecto, Charney destaca la importancia de una protección efectiva de estos discursos, por lo que cuestiona los alcances de las normas penales que protegen los derechos de la personalidad, en tanto limiten desproporcionadamente la libertad de expresión. CHARNEY (2016), pp. 12 y ss.

${ }^{99}$ Fiss precisa que dicha pretensión no debe constituir un mecanismo de inhibición y que la indemnización deberá ser amparada sólo en tanto se compruebe la falsedad de la información y dicho disvalor coincida con el conocimiento de la falsedad y el temerario desprecio por conocer la verdad. FISS (2004), pp. 15 y s.

${ }^{100}$ MIR PUIG (2011), p. 528.
} 
cumplan con la exigencia de veracidad y observen el principio de la dignidad. ${ }^{101}$ Por ello, aquellas expresiones que sean abiertamente injuriosas o innecesariamente lesivas al principio de dignidad de las personas, aún si versaran sobre asuntos de relevancia pública y sean veraces, no pueden considerarse como ejercicios legítimos del derecho a la libertad de expresión.

La colisión entre la expectativa de protección jurídico penal del bien jurídico del honor, frente a la libertad de expresión, configura un conflicto de intereses característico de toda causa de justificación. En el caso de los actos comunicativos relativos al interés público, esta operación debe ser previa y operar en sede de tipicidad, de tal manera que dichas conductas queden fuera del ámbito penal. La postura contraria a la despenalización de los delitos contra el honor, abogan por mantener el análisis del referido conflicto en sede de antijuridicidad ya que la valoración negativa de las conductas lesivas del honor y del resultado típico es un presupuesto implícito de la norma prohibitiva contenida en el tipo base de la injuria. ${ }^{102}$

Consideramos que los ejercicios legítimos de libertad de expresión cumplen con las exigencias del sistema jurídico, es decir, no exceden ni son contrarias a lo jurídicamente permitido. Por ello, mantener los actos comunicativos de interés público dentro del conjunto de conductas tipificadas como delitos contra el honor, resulta contrario a los principios de idoneidad y lesividad. Cabe indicar que, al excluir los ejercicios comunicativos relativos al interés público del ámbito penal, basándonos en la suficiencia normativa de este criterio, optamos por una postura utilitaria moderada que no deja de lado las observaciones formuladas por la jurisprudencia paradigmática respecto de la protección de los derechos de la personalidad. ${ }^{103}$

En relación a la despenalización de los discursos de interés público, la aceptación de los actos comunicativos referidos a funcionarios públicos evidencia una valoración social positiva, sobre todo cuando provienen de la actividad periodística que fiscaliza el ejercicio del poder. En este sentido, el criterio del interés público opera como factor excluyente de tipicidad de aquellas conductas en la que los sujetos pasivos son personajes adscritos en el ámbito subjetivo de dicho criterio, por lo que resultan socialmente adecuadas. En este sentido, procederemos a someter la fórmula normativa $\left(\mathrm{N}_{1} \wedge \mathrm{e}^{\prime}\right)$ al test de ponderación, para visualizar las objeciones a nivel material que se han advertido anteriormente.

Partiendo de la concepción conflictivista, la colisión entre las posiciones iusfundamentales del honor y la libertad de expresión que se observan en la referida fórmula normativa, operará desde el ámbito de los derechos de defensa, es decir, de los derechos a acciones negativas. En el caso del derecho a la libertad de expresión, el derecho a expresar opiniones e informaciones sin impedimento y en el caso del derecho al honor, el derecho a no sufrir afectaciones por dichas expresiones. Al excluir los actos de interés público que pueden resultar lesivos para el honor de los funcionarios públicos se configura una intervención en

\footnotetext{
101 GÓMEZ (2017), pp. 21 y ss.

${ }^{102}$ Meini considera equivocado asumir las premisas de la posición conflictivista. En este sentido, aboga para que en el caso de difamación agravada, la acción penal no sea privada sino pública. MEINI (2009), p. 364. Confróntese, PEÑA (2015), pp. 303 y ss.

${ }^{103}$ MIR PUIG (2011), p. 428 y ss. Al respecto, Dworkin, precisa que en el caso de la prensa, la valoración positiva del público se debe a la creencia de que ella "constituye una sabia limitación al secretismo y desinformación oficiales". Ello se debe al rol que desempeña en el sistema de controles equilibrados de poder, al investigar e informar sobre las irregularidades advertidas en las actividades gubernamentales. DWORKIN (2019), p. 228.
} 


\section{Polit. Crim. Vol. 15, № 30 (Diciembre 2020), Art. 16, pp. 1009 - 1051 [http://politcrim.com/wp-content/uploads/2020/12/Vol15N30A16.pdf]}

el derecho al honor, cuyo operador estaría representado por $\left(\mathrm{I}_{1}\right)$. Como contrapartida, mantener la penalización de dichas conductas como elementos constitutivos del tipo, implica una inervención en el derecho a la libertad de expresión representada por $\left(\mathrm{I}_{2}\right)$.

En la primera intervención $\left(\mathrm{I}_{1}\right)$, la fórmula normativa afecta el derecho al honor de un grupo de personas en razón de un estándar objetivo que los ubica como sujetos que ejercen funciones públicas, Por ello en principio, estarían llamados a ser fiscalizados permanentemente y rendir cuentas de sus actos. En este sentido, la lesión del honor ante la difusión de hechos noticiosos que afecten este bien jurídico, denotan una intensidad leve. Los puntos relativos a la asignación de peso abstracto y a la seguridad en las premisas empíricas se aprecian en el desarrollo jurisprudencial en relación a la afectación del honor discutida en sede judicial, donde los funcionarios públicos cuentan con recursos para responder las imputaciones de la prensa, dando como resultado una afectación leve del derecho al honor.

En la ponderación de la segunda intervención $\left(\mathrm{I}_{2}\right)$, se aprecia una afectación intensa al derecho a la libertad de expresión, ya que no se diferencian los actos comunicativos relativos al interés público. Es decir, los funcionarios públicos además de contar con capacidad de respuesta para contestar una imputación haciendo uso de los medios y del interés que suscitan sus declaraciones, también cuentan con una norma para la protección del honor que les otorga una ventaja frente al común de los ciudadanos. Por ello, una norma penal que no excluya los actos comunicativos referidos a asuntos de interés público representa una intervención intensa en el derecho a la libertad de expresión.

En sede de idoneidad se ubica el nexo de causalidad positivo entre el objeto que la fórmula normativa busca proteger y la afectación del derecho fundamental a la libertad de expresión. En dicha relación se observa que el derecho al honor es afectado por el ejercicio de la libertad de expresión. Sin embargo, dicha afectación no es intensa ya que la emisión de una opinión puede ser debatible y contestada en el marco del sistema democrático sin recurrir a una norma penal, de conformidad con el principio de ultima ratio. Asimismo, prima el derecho a la libertad de expresión e información, al encontrarnos en un supuesto de interés público, máxime si este ejercicio también observa los otros criterios que le dotan de legitimidad, tales como la exigencia de veracidad ausencia de expresiones vejatorias.

El problema de la norma penal que no diferencia los actos comunicativos relativos al interés público se observa con mayor claridad al aplicar el sub principio de necesidad. Al existir otras medidas que salvaguardan el honor tales como la acción civil por responsabilidad extracontractual o las medidas reparadoras simbólicas, las exigencias de este sub principio no son superadas. Una eficacia similar, desarrollada por la doctrina, se aprecia en la exigencia del derecho a la rectificación, ya que cuando un medio corrige la información difundida y la ajusta a las exigencias de veracidad, el honor resulta reparado sin la intervención del Derecho Penal. ${ }^{104}$

La regulación penal de los ilícitos contra el honor que no toma en cuenta la existencia de medidas alternativas más eficaces y menos lesivas para el ejercicio del derecho a la libertad de expresión, no satisface el sub principio de necesidad. En consecuencia, los resultados de

${ }^{104}$ Cabe advertir que la rectificación es un derecho autónomo que no se sujeta necesariamente al contenido protegido del derecho al honor, pese a presentar zonas de coincidencia. Confróntese, COMISIÓN INTERAMERICANA DE DERECHOS HUMANOS. Exigibilidad del derecho de rectificación o respuesta. Opinión Consultiva OC-7/86, solicitada por el gobierno de Costa Rica, 29 de agosto, San José, 1986. 
una aplicación del sub principio de proporcionalidad en sentido estricto darían el mismo resultado. ${ }^{105}$ Observamos que la aplicación del interés público como un estándar del ejercicio legítimo del derecho a la libertad de expresión facilita la distinción de aquellos actos que ameritan protección reforzada. También permite plantear una fórmula normativa a partir de dicho criterio, en tanto regla de precedencia, para resolver los conflictos iusfundamentales entre el derecho al honor y el derecho a la libertad de expresión. Esta aplicación, sumada a los criterios para la exclusión de tipicidad y la aplicación del test de ponderación, permiten cuestionar el fundamento de la protección penal del honor que no diferencia los discursos de interés público.

En síntesis, el test de ponderación permite apreciar que la sanción penal para la protección del honor resulta idónea pero no necesaria, dada la capacidad de otros mecanismos para resarcir el derecho al honor. Entre ellos tenemos: la determinación de la responsabilidad extracontractual, la restitución a través de medidas simbólicas de reparación y en especial un mayor ejercicio del derecho a la rectificación. Se observa, también, que la protección del bien jurídico honor no pasa necesariamente por la sanción penal de las conductas que lesionan dicho bien jurídico, por lo que este tratamiento debe responder a las exigencias de una política criminal moderna, en concordancia con el principio democrático y la dignidad humana.

\section{Apreciación del interés público en las propuestas del legislador peruano para la despenalización de los delitos contra el honor cometidos a través de la prensa}

\subsection{Cuestiones previas}

En la discusión para despenalizar de los delitos contra el honor, cometidos a través de la prensa, cobran especial relevancia las instituciones del Sistema Interamericano de Derechos Humanos y las organizaciones de la sociedad civil. Al respecto, tenemos el desarrollo jurisprudencial de la Corte IDH y la promoción que realiza la RELE de los estándares convencionales para la protección de la libertad de expresión por parte de las cortes domésticas. ${ }^{106}$ Estas instituciones tienen repercusiones importantes dado el marco normativo convencional que se desprende del artículo 2 de la Convención Americana sobre Derechos Humanos, y las obligaciones de los Estados parte, para adecuar su legislación nacional a los estándares interamericanos. Coadyuvan las actividades efectuadas por organismos no gubernamentales que difunden y mantienen la vigencia de esta discusión a partir de sus respectivos trabajos de investigación y actividades de incidencia. ${ }^{107}$ En conjunto, incidieron

\footnotetext{
105 Una propuesta para enfocar la atención en las medidas alternativas, ha sido elaborada por la Corte IDH al evaluar las medidas de satisfacción, específicamente aquellas que consisten en la divulgación de la sentencia a costa del responsable de los actos lesivos para el honor. Su promoción debe estar orientada, entre otras, a la mayor difusión de la exigencia efectiva del derecho de rectificación y de los mecanismos de sanción extrapenal. Estas medidas pueden coexistir y potenciarse con la protección civil del derecho al honor a través del mecanismo de la responsabilidad civil. La eficacia de estas soluciones tienen un grado de reproche significativo y no requieren de la intervención del ius puniendi, además se orientan a reparar el honor y a incidir en los deberes éticos del comunicador ante la difusión de información inexacta o vejatoria. En el ámbito peruano, apreciamos el tenor de la sentencias del Caso Comunidad Nativa Sawawo Hito 40, Exp. No 04611-2007$\mathrm{PA} / \mathrm{TC}$, en la que el Tribunal Constitucional valoró la vía civil y el amparo como medidas alternativas a las querellas penales. Confróntese, MEJÍA (2016), p 233.

${ }^{106}$ RELATORÍA (2009), pp. 7 y ss.

${ }^{107} \mathrm{Al}$ respecto, observamos una experiencia de confluencia entre órganos del sistema universal y regional de protección de los derechos humanos y de los organismos no gubernamentales especializados en el tema de la promoción de las libertades comunicativas y el ejercicio periodístico. Se trata del curso denominado "Marco jurídico internacional de la libertad de expresión, acceso a la información pública y protección de periodistas",
} 


\section{Polít. Crim. Vol. 15, № 30 (Diciembre 2020), Art. 16, pp. 1009 - 1051 [http://politcrim.com/wp-content/uploads/2020/12/Vol15N30A16.pdf]}

en los procesos para la propuesta de mecanismos alternativos a la vía penal, e idóneos para proteger o resarcir el honor, y contribuyen a la tendencia a favor de la despenalización de los delitos contra el honor.

Como resultado de la dinámica descrita, observamos los procesos de despenalización del delito de desacato. ${ }^{108}$ Este es un antecedente importante que da cuenta de la relevancia del criterio interés público y sus consecuencias prácticas para el razonamiento legislativo. En el año 1995, a partir del proceso de solución amistosa del Caso Verbitsky vs. Argentina, la CIDH expresó su reconocimiento al gobierno argentino por derogar el desacato de su legislación. ${ }^{109}$ Posteriormente, en el Caso Palamara Iribarne vs. Chile, la Corte IDH resaltó que la aplicación del tipo penal de desacato constituía una forma de persecución penal desproporcionada e innecesaria en una sociedad democrática y enfatizó que la imposición de este tipo de sanciones constituye restricciones innecesarias del derecho a la libertad de pensamiento y de expresión. ${ }^{110}$

En el caso peruano, el cambio del escenario político en el año 2000 trajo, entre otros, la restitución del orden democrático constitucional y la observancia de los deberes internacionales del Estado peruano en materia de protección de los derechos humanos. ${ }^{111}$ Este contexto, permitió retomar la discusión sobre la protección penal del honor y su conflicto con la libertad de expresión. Así, en el año 2003 se derogó el artículo 374 de la norma sustantiva que establecía el delito de desacato. Dicho proceso constituyó una respuesta adecuada al problema de la protección reforzada del honor de los funcionarios públicos, ${ }^{112}$ lo que configuraba una situación de privilegio y lesionaba desproporcionadamente el derecho a la libertad de expresión.

Una vez derogado el delito de desacato, las querellas formuladas por funcionarios públicos contra periodistas, pusieron el tema de la protección penal del honor frente a una nueva discusión: los riesgos de la instrumentalización de los tipos penales de la calumnia o la injuria. ${ }^{113}$ Este problema explica la constante recomendación a favor de la despenalización de los delitos contra el honor por parte de la CIDH. Resalta la experiencia argentina que tuvo

el cual apunta a lograr una incidencia específica en la interpretación de los conflictos sobre la libertad de expresión, en los operadores judiciales en más de veinte países de América Latina, desde el 2015. En https://bit.ly/2NHwIoW [visitado el 21.10.2018].

${ }^{108}$ A la fecha, este delito continúa vigente en los respectivos códigos penales de El Salvador (artículo 339) y Nicaragua (artículo 462), en: COMITÉ - CPJ (2015), passim.

${ }^{109}$ Argentina derogó el tipo penal de desacato, regulado en los artículos 244 del Código Penal y el artículo 6 de la Ley $\mathrm{N}^{\circ}$ 13985, mediante la Ley 24.198 en el año 1993, en el marco del acuerdo de solución amistosa del caso Verbitsky ante la Comisión Interamericana de Derechos Humanos. COMISIÓN INTERAMERICANA, Informe $\mathrm{N}^{\circ} 22 / 94$, párr. 22.

110 CORTE INTERNAMERICANA DE DERECHOS HUMANOS, Caso Palamara Iribarne vs. Chile. Sentencia del 22 de noviembre de 2005. Serie C N 135 , párr. 88.

${ }^{111}$ Confróntese, GARCÍA y EGUIGUREN (2018), p. 378.

${ }^{112} \mathrm{Al}$ respecto cabe anotar que la regulación del delito de desacato establecía una mayor protección del honor del funcionario tanto en la pena privativa de la libertad, como en la persecución del delito, ya que interviene el Ministerio Público. Dicha desigualdad era injustificada dado que el funcionario debe soportar un riesgo mayor de ataques a su honor, en virtud del interés público que sustenta la crítica sobre sus actividades y actitudes. CARO (2002), p. 67.

${ }^{113}$ ITURRALDE (2001), pp. 9 y ss.; Confróntese con los estudios y reportes sobre niveles de libertad de prensa y condiciones para ejercer el periodismo, entre los que destacan: Freedom House, Reporteros sin Fronteras y Comité para la Protección de los Periodistas. Estos coinciden en señalar a los procesos judiciales contra periodistas, como una modalidad de persecución del trabajo periodístico. En: https://bit.ly/2WKVOaw, [visitado el 21.09.2018]. 
como uno de sus factores al proceso de solución amistosa del caso Kimel vs. Argentina. ${ }^{114}$ Dicha reforma, aplicó el interés público como criterio normativo que constituye un supuesto de atipicidad introducido mediante la Ley $\mathrm{N}^{\circ} 26.551 .{ }^{115}$

La despenalización del delito de desacato y los procesos de reforma para despenalizar los delitos contra el honor, recogen los principales aportes jurisprudenciales, recomendaciones, observaciones y trabajo de incidencia, de las instituciones del SIDH y de las organizaciones de la sociedad civil, respectivamente, cuyos argumentos pueden sintetizarse en los siguientes términos: a) eliminar la utilización de procesos penales para proteger el honor y la reputación cuando se difunde información sobre asuntos de interés público, relativas a funcionarios públicos, candidatos para ejercer cargos públicos, y personajes de relevancia pública; b) modificar los dispositivos normativos, que desde el Derecho Penal, regulan los ilícitos contra el honor respecto de ideas o instituciones con el fin de contrarrestar el efecto inhibidor en el libre debate democrático; y c) establecer regulaciones que garanticen la libre crítica social en asuntos que afecten a la comunidad jurídico política.

\subsection{Dinámica en el razonamiento legislativo}

La discusión sobre la despenalización de los delitos contra el honor, en el contexto peruano, da cuenta de la interacción de tres factores: a) el desarrollo progresivo de una línea jurisprudencial que denota la aplicación de las modernas doctrinas sobre la libertad de expresión, la resolución de los conflictos iusfundamentales entre el derecho a la libertad de expresión, y la doctrina penal sobre el derecho al honor; b) las exigencias del deber de adecuación de la normativa interna a las obligaciones convencionales, así como la incorporación de los estándares jurisprudenciales para la protección de la libertad de expresión elaborados por la Corte IDH y de las recomendaciones formuladas por la CIDH y la RELE, en el razonamiento de los jueces peruanos; y c) las actividades de incidencia emprendidas por las organizaciones de la sociedad civil y la judicatura. A nivel legislativo, la confluencia de los referidos factores se tradujo en una respuesta institucional para reformar el tenor de las normas penales que constituyen una intervención intensa en el ejercicio del derecho a la libertad de expresión e información, entre los años 2006 y 2019.

\subsubsection{Proyecto de Ley $\mathrm{N}^{\circ} 912 / 2006-\mathrm{CR}$}

La primera iniciativa legislativa que propuso la despenalización de los delitos contra el honor cometidos a través de la prensa fue el Proyecto de Ley N ${ }^{\circ}$ 912/2006-CR (Proyecto 2006). ${ }^{116}$ $\mathrm{Su}$ fórmula legal consistía en reformar el párrafo segundo del inciso 4) del artículo 2 de la Constitución Política, y derogar los artículos $130^{\circ}$ al $138^{\circ}$ del Código Penal. En la exposición de motivos, el autor sustentó mediante fundamentos convencionales y constitucionales la importancia de la tendencia hacia la despenalización de los delitos contra el honor relacionados con las críticas a personajes públicos. ${ }^{117}$ Aquél fue su principal argumento, denotando así la centralidad del interés público en su dimensión subjetiva.

\footnotetext{
${ }^{114}$ CORTE INTERNAMERICANA, Caso Kimel vs. Argentina, párr. 59.

115 Aprobada el 27 de noviembre de 2009. Modificó los artículos 109 y 110 del Código Penal argentino. Dicha iniciativa legislativa fue propuesta por el Poder Ejecutivo, cuyo proyecto inicial proponía la sustitución de los artículos 109, 110, 111, 113, 117 y la derogación del artículo 112 del Código Penal, que versaban sobre los delitos de calumnias e injurias. Proyecto de Ley 63/09. Presentado el 29 de octubre de 2009. En: https://bit.ly/2FA9hgt [visitado el 20.09.2017]

${ }^{116}$ Presentada el 23 de enero del año 2007, por el entonces congresista de la célula parlamentaria aprista, Javier Valle Riestra. Expediente digital en: https://bit.ly/34jb6Wu [visitado el 12.02.2017].

${ }^{117}$ Exposición de motivos del Proyecto 2006, pp. 10 y ss.
} 
Ante la colisión iusfundamental entre las libertades comunicativas y los derechos de la personalidad, el legislador consideró necesaria la reforma de la Constitución para derogar los tipos penales que protegen el derecho al honor. Este razonamiento, consideró dicha reforma como condición previa para que los ilícitos contra el honor pasasen del ámbito penal al civil. ${ }^{118}$ Dicha reforma no era necesaria ya que el legislador podía sostener la despenalización a partir de una interpretación flexible y sistemática de la Constitución, conforme el principio de concordancia práctica.

En su exposición de motivos señaló la necesidad de despenalizar estos delitos, ya que aquellos casos trascendentes para la comunidad jurídico política requieren máxima difusión y contar con las condiciones que faciliten un debate más amplio. ${ }^{119}$ Bajo dicho razonamiento, el trabajo periodístico así como la difusión de información y opiniones debían gozar de una protección reforzada. Esta postura acoge en gran medida los aportes de la teoría de los derechos preferentes. En este sentido, observamos la aplicación de la dimensión republicana del interés público que otorga mayor importancia al proceso democrático. También señaló que la intervención en la esfera del derecho a la libertad de expresión, mediante estos delitos, resulta innecesaria y configura un obstáculo para maximizar el debate público.

Una deficiencia en este proyecto es la ausencia de una justificación más elaborada sobre la protección del honor en el ámbito civil. Esto se debe a la falta de un adecuado ejercicio de ponderación entre los derechos que conforman el referido conflicto iusfundamental. Llama la atención, tanto en el debate en la Comisión de Constitución y Reglamento del Congreso como en el pleno, que estas deficiencias no fueran advertidas por los opositores de la reforma planteada, lo que no permitió su mejora desde una racionalidad deliberativa. Al no generar consensos fue desestimada y archivada el 27 de octubre del 2009.

\subsubsection{Proyecto de Ley $\mathrm{N}^{\circ} 4581-2010-\mathrm{CR}$}

Un año después, el Proyecto de Ley N ${ }^{\circ}$ 4581-2010-CR (Proyecto 2010) propuso tipificar la injuria racista y consignar el límite máximo de la pena privativa de la libertad en tres años si era cometida a través del libro, prensa u otro medio de comunicación social. ${ }^{120}$ El legislador consideró que aquellas palabras, gestos o vías de hecho que contribuyesen a promover actos discriminatorios por motivo racial o de identidad étnica ameritaban ser consideradas como agravantes del delito de injuria, o de difamación si eran cometidas por medio de libro, prensa u otro medio de comunicación social. Sin embargo, el texto sustitutorio del referido proyecto, reemplazó las penas privativas a la libertad por prestación de servicios a la comunidad y días multa, tanto para el delito de injuria como para el de difamación, regulados en los artículos 130 y 132, del Código Penal, respectivamente. ${ }^{121}$

\footnotetext{
${ }^{118} \mathrm{Al}$ respecto, el ex congresista Valle Riestra expuso que la reforma constitucional podía darse a la par que la derogación de los delitos contra el honor. En respuesta, los representantes de la Defensoría del Pueblo y del Colegio de Abogados de Lima, sostuvieron que debía primar una interpretación pro homine, que favoreciera la ampliación de los derechos y que la Constitución no establecía la obligación de reformarla para extraer los ilícitos contra el honor del ámbito penal. COMISIÓN DE CONSTITUCIÓN Y REGLAMENTO DEL CONGRESO, transcripción del acta del 15 de setiembre de 2009, en: https://bit.ly/2NQPw5b [visitado el 14.02.2017].

${ }^{119}$ Presentada el 23 de enero del año 2007, por el entonces congresista de la célula parlamentaria aprista, Javier Valle Riestra. Expediente digital en: https://bit.ly/34jb6Wu [visitado el 12.02.2017].

${ }^{120}$ Proyecto presentado por el ex congresista Juvenal Silva presentó el Proyecto de Ley $\mathrm{N}^{\circ}$ 4581/2010-CR, el 16 de diciembre del año 2010. Expediente digital en: https://bit.ly/2WL4Fcg [visitado el 18.02.2017]

${ }^{121}$ Texto sustitutorio de fecha 14 de julio del año 2011. En: https://bit.ly/2NfB4Vf [visitado el 18.02.2017]
} 
Esta iniciativa legislativa abordó el conflicto iusfundamental entre la libertad de expresión y el honor mediante la doctrina de los discursos de odio referidos al racismo. ${ }^{122} \mathrm{Al}$ asumir la doctrina de los discursos especialmente protegidos en su dimensión negativa sobre los discursos de odio, distinguió aquellos ejercicios comunicativos que no gozan de la protección del derecho a la libertad de expresión, por vulnerar normas constitucionales y convencionales que protegen a minorías y a sectores sociales en situación de vulnerabilidad. Este razonamiento da cuenta de una aplicación más amplia del interés público conforme las exigencias del pluralismo jurídico. Si bien las manifestaciones que vulneran el principio de la dignidad humana, tales como las expresiones racistas, sexistas, homofóbicas o xenofóbicas no pueden ser considerados ejercicios legítimos de la libertad de expresión, se observa que las expresiones de injuria racista podían subsumirse en el delito de discriminación. ${ }^{123}$ En todo caso, al reiterar el objeto jurídico protegido en el tipo penal de discriminación, el legislador no identificó como concepto central de su argumentación al interés público, desde una perspectiva liberal únicamente, sino más bien republicana y enfocada en la protección de los derechos fundamentales conforme a las exigencias del pluralismo. ${ }^{124}$

El texto sustitutorio de este proyecto incluyó la figura de la injuria racista y reformuló las penas para los delitos de injuria y difamación. Propuso dejar de lado la pena privativa de la libertad, reemplazándola por jornadas de servicio comunitario y días multa. La fórmula legislativa inicial no propuso la despenalización sino una modificación significativa de las penas de los delitos contra el honor cometidos a través de la prensa, excluyendo la privación de la libertad. Lo cual, generó consensos entre los legisladores por lo que fue aprobado en el pleno del Congreso. Sin embargo, la autógrafa de la ley fue observada por el Poder Ejecutivo, lo que impidió su promulgación y derivó en su archivo. La relevancia de este proyecto de ley radica en haber planteado como política criminal excluir la pena privativa de la libertad para los delitos contra el honor.

\subsubsection{Proyecto de Ley $\mathrm{N}^{\circ} 459-2011-\mathrm{CR}$}

Pocos meses después, ya instalado un nuevo gobierno y un nuevo parlamento, fue presentado el Proyecto de Ley $\mathrm{N}^{\circ}$ 459-2011-CR (Proyecto 2011), cuya propuesta consistía en derogar el delito de difamación cometido por medio de la prensa u otro medio de comunicación social. ${ }^{125}$ Esta iniciativa legislativa asumió los alcances de la teoría de los derechos

\footnotetext{
${ }^{122}$ El planteamiento de este proyecto recoge los aportes de la protección diferenciada de los discursos señalada por la Relatoría Especial para la Libertad de Expresión. Conforme lo establecido en el artículo 13.5 de la Convención Americana de Derechos Humanos, los discursos racistas exigen un rol activo del Estado para desincentivarlos, dado su rol garante del proceso democrático y de los derechos de las minorías.

${ }^{123}$ Tipificado en el Código Penal, Título XIV-A, Delitos contra la humanidad, Capítulo IV, artículo 323, cuyo texto indica: "El que por sí o mediante terceros, discrimina a una o más personas o grupo de personas, o incita o promueve en forma pública actos discriminatorios, por motivo racial, religioso, sexual, de factor genético, filiación, edad, discapacidad, idioma, identidad étnica y cultural, indumentaria, opinión política o de cualquier índole o condición económica, con el objeto de anular o menoscabar el reconocimiento, goce o ejercicio de los derechos de la persona, será reprimido con pena privativa de libertad no menor de dos años, ni mayor de tres o con prestación de servicios a la comunidad de sesenta a ciento veinte jornadas (...)"

${ }^{124} \mathrm{La}$ argumentación de la propuesta inicial, recoge los fundamentos expresados por el Tribunal Constitucional peruano en el caso CAPECO, Exp. № 0261-2003-AA/TC. Asimismo, en el caso Comunidad Nativa Sawawo Hito 40, Exp. N N $^{\circ}$ 4611-2007-PA/TC, abordó dichas exigencias en los fundamentos de los votos de los magistrados Eto y Landa.

${ }^{125}$ Iniciativa presentada el 03 de noviembre del año 2011, por el entonces congresista Heriberto Benítez. Su propuesta consistía en derogar el último párrafo del artículo $132^{\circ}$ del Código Penal y el artículo $314^{\circ}$ del Código
} 


\section{Polít. Crim. Vol. 15, No 30 (Diciembre 2020), Art. 16, pp. 1009 - 1051 [http://politcrim.com/wp-content/uploads/2020/12/Vol15N30A16.pdf]}

preferentes y dejó de lado los límites internos y externos de la libertad de expresión. El legislador desarrolló su argumentación basándose en la dimensión objetiva del interés público, lo que le llevó a resaltar la importancia de la libertad de prensa para fortalecer el sistema democrático y la crítica social. Este razonamiento recogió la valoración positiva del rol de los medios de comunicación y su importancia en los procesos de investigación y denuncia contra ilícitos cometidos por funcionarios públicos y la problemática del crimen organizado. Sin embargo, no ofreció mayores argumentos en relación a la protección del derecho al honor, incluso justificó que el ejercicio periodístico pueda cometer excesos, en tanto estos constituyen un riesgo que debe ser tolerado. ${ }^{126}$

Pese a que este proyecto recogió parte importante de los argumentos basados en el interés público, más resaltantes de la corriente despenalizadora, no incluyó los aportes de los discursos especialmente protegidos, ni ponderó la afectación del derecho al honor. Dicho déficit argumentativo conllevaría a una afectación desproporcionada a los derechos de la personalidad. En la actualidad, esta propuesta legislativa forma parte del Dictamen de la Comisión de Justicia y Derechos Humanos para la elaboración del proyecto de Nuevo Código Penal. ${ }^{127}$ Dicho cuerpo normativo mantiene la pena privativa de la libertad para el delito de difamación cometida a través de la prensa, en su límite máximo, lo que da cuenta de un alejamiento tanto de la fórmula legislativa del Proyecto de Ley $\mathrm{N}^{\circ}$ 459-2011-CR como de la tendencia regional hacia la despenalización.

\subsubsection{Proyecto de Ley $N^{\circ} 4184 / 2018-C R$}

Recientemente, el legislador peruano retomó la discusión sobre la despenalización de los delitos contra el honor mediante el Proyecto de Ley No 4184/2018-CR (en adelante, Proyecto 2018). ${ }^{128}$ Esta iniciativa tiene varias particularidades en relación a los proyectos anteriores. En primer lugar, expone de manera suficiente los fundamentos constitucionales al reconocer el conflicto entre el derecho al honor y el derecho a la libertad de expresión e información. En segundo lugar, aplica el test de ponderación para determinar, a nivel abstracto, si la penalización de determinados ejercicios comunicativos resulta idónea, necesaria y proporcional. Concluye que la opción de política criminal vigente, es idónea pero no necesaria, ni proporcional, dado que existen formas menos lesivas para sancionar las afectaciones del derecho al honor, las cuales no impactan negativamente en la deliberación pública.

Dado que la regulación penal de los ilícitos contra el honor no superan el test de ponderación, el legislador propone una fórmula legal en la que establece un mecanismo para hacer efectiva

\footnotetext{
de Procedimientos Penales. Fue incluido en el conjunto de las iniciativas que regulaban, incluían nuevas conductas o agravaban las penas de diferentes tipos penales. Por ejemplo, el Proyecto Legislativo $\mathrm{N}^{\circ}$ 4833/2015-CR presentado el 18 de setiembre del año 2015 por el ex congresista Wilder Ruiz Loayza, que proponía incluir dentro del tercer párrafo del artículo $132^{\circ}$ del Código Penal conductas ilícitas sobre el uso de medios virtuales tales como blogs y páginas sociales. La propuesta legislativa de Benítez fue agrupada junto con otros 195 proyectos legislativos en el Dictamen de la Comisión de Justicia y Derechos Humanos, de fecha 9 de mayo del 2016, proyecto de Nuevo Código Penal. Expediente digital unificado en: https://bit.ly/2C8XEs5 [visitado el 26.03.2017].

${ }^{126}$ Texto de la primera versión del proyecto en: https://bit.ly/2pGz7bl [visitado el 11.04.2017].

${ }^{127}$ CONSEJO NACIONAL DE POLÍTICA CRIMINAL (2016), passim.

${ }^{128}$ Proyecto $\mathrm{N}^{\circ} 4184 / 2018$-CR, presentado el 10 de abril del 2019.
} 
la rectificación vía conducto notarial. ${ }^{129}$ También establece una escala de multas como sanción a imponer en caso de que el juez falle a favor del agraviado. ${ }^{130}$ Aclara que dicha sanción deja abierta la posibilidad de recurrir al fuero civil para reclamar la respectiva indemnización. De esta manera, justifica que los ilícitos contra el honor sean excluidos del ámbito penal y pasasen el ámbito civil.

Los argumentos ofrecidos en el Proyecto de Ley № 4184/2018-CR, se adscriben en la corriente para la despenalización impulsada desde los órganos del Sistema Interamericano de Derechos Humanos. Además del reconocimiento explícito que el legislador otorga al marco normativo y jurisprudencial del referido sistema, en su exposición de motivos, también expone el tenor de las recomendaciones de la RELE emitidas desde el año 1998. ${ }^{131}$ También hace lo propio con las recomendaciones formuladas por los representantes de las diferentes relatorías para la libertad de expresión, las cuales fueron sintetizadas en la Declaración Conjunta sobre los Mecanismos Internacionales para la Promoción de la Libertad de Expresión. Documento en el que se expuso, entre otros, la necesidad de revisar la legislación interna sobre los tipos penales para la protección del honor y trasladarlos al fuero civil.

A diferencia de los anteriores, este proyecto, no se limitó a excluir los ilícitos contra el honor del ámbito penal, en base a argumentos de carácter autoritativo, sino que explicitó los términos del conflicto entre el derecho al honor y el derecho a la libertad de expresión e información, mediante el test de ponderación. Elaboró una evaluación en sede abstracta a partir de la aplicación del interés público en sus dimensiones republicana y liberal, ya que no descuidó la protección de los espacios para la deliberación democrática, ni la vigencia de los derechos fundamentales.

Este proyecto de ley refleja mayor consistencia entre los deberes de argumentación de un legislador racional, al optar por una política criminal acorde a las exigencias del marco constitucional y convencional. Asimismo, fue en sentido contrario a la tendencia observada en el período legislativo comprendido entre los años 2016 al 2019. ${ }^{132}$ Dicho período denotó una línea legislativa orientada a restringir mediata o inmediatamente las libertades comunicativas, contraria a la valoración positiva del rol que desempeñaron los medios de comunicación, en especial, el periodismo de investigación frente a los casos de corrupción revelados a partir del caso Lava Jato. ${ }^{133}$ Pese a los aciertos advertidos, y por razones de carácter político e institucional, este proyecto no llegó a debatirse en las respectivas comisiones parlamentarias, debido al cierre del Congreso.

\footnotetext{
129 Art. 6 de la fórmula legal, Proyecto $\mathrm{N}^{\circ}$ 4184/2018-CR, presentado el 10 de abril de 2019 por los representantes parlamentarios de la Bancada Liberal. Expediente parlamentario virtual en: https://bit.ly/2qiooUm [visitado el 20.07.2019], p. 2.

130 Art. 11 de la fórmula legal, Proyecto $N^{\circ} 4184 / 2018-C R$, presentado el 10 de abril de 2019 por los representantes parlamentarios de la Bancada Liberal. Expediente parlamentario virtual en: https://bit.ly/2qiooUm [visitado el 20.07.2019] p. 4.

${ }^{131}$ Exposición de motivos, Proyecto No 4184/2018-CR, presentado el 10 de abril de 2019 por los representantes parlamentarios de la Bancada Liberal. Expediente parlamentario virtual en: https://bit.ly/2qiooUm [visitado el 20.07.2019], p. 8.

${ }^{132}$ CALDERÓN (2018), passim.

133 En especial, los proyectos legislativos $N^{\circ}$ 233/2016-CR, $N^{\circ} 1120 / 2016-C R, N^{\circ} 3990 / 2018-C R, N^{\circ}$ 4275/2018-CR.
} 


\section{Polít. Crim. Vol. 15, No 30 (Diciembre 2020), Art. 16, pp. 1009 - 1051 [http://politcrim.com/wp-content/uploads/2020/12/Vol15N30A16.pdf]}

\subsection{Balance $y$ perspectivas}

Evaluar una argumentación legislativa supone asumir algunos criterios de corrección que permitan diferenciar entre un mayor o menor peso justificativo o efecto persuasivo. ${ }^{134}$ Asimismo, requiere de pautas para una evaluación racional de las leyes penales, donde la política criminal y el control a nivel constitucional y convencional cumplen un rol fundamental. En este sentido, analizaremos el razonamiento jurídico del legislador a nivel formal, material y pragmático.

\subsubsection{Nivel formal}

Los deberes de motivación, en el marco de una racionalidad legislativa, comprenden la necesidad de comunicar con claridad los enunciados tanto a los posibles afectados por la norma como a quienes deban aplicarla. En este sentido, la comparación de las cuatro iniciativas permite deducir formalmente que el criterio de interés público deriva de una perspectiva republicana de la libertad de expresión; inferencia que resulta más clara en tres de ellos: Proyecto 2006, Proyecto 2011 y Proyecto 2018.

Sin embargo, sólo el Proyecto 2006 y el Proyecto 2018 ofrecieron una propuesta más completa y técnica de la despenalización de los delitos contra el honor y su traslado a la esfera civil. Mientras que en el primero de ellos, el legislador consideró necesaria una reforma constitucional previa, ninguno de los proyectos posteriores siguió dicho razonamiento. Salvo el texto sustitutorio del Proyecto 2010 que propuso eliminar las penas privativas de la libertad para los delitos contra el honor, los demás proyectos no denotan tal grado de precisión en sus respectivas técnicas legislativas.

Parte de las falencias que observamos en la aplicación del interés público se debe a la ausencia de una delimitación conceptual de este criterio. Pese a no circunscribirse en el conjunto de iniciativas legislativas para la despenalización del honor, destaca el trabajo conceptual del Proyecto de Ley No 4899/2010-PJ (Proyecto 2010-PJ). Si bien su foco eran los tipos penales de interceptación, interferencia y difusión de las comunicaciones privadas, de la mano con una marcada crítica hacia los medios de comunicación por difundir noticias provenientes de interceptaciones telefónicas no autorizadas judicialmente, este proyecto representa un avance importante para abordar la discusión sobre la despenalización ya que precisó los alcances conceptuales del interés público, como primer espacio de análisis sobre la legitimidad de un acto comunicativo. ${ }^{135}$

Frente a dicha problemática, la Corte Suprema del Perú elaboró la referida iniciativa legislativa, cuyo objeto normativo consistía en precisar los alcances de los delitos

\footnotetext{
134 “[...] dictar una ley supone la pretensión de lograr un cierto objetivo social (razones teleológicas), que pueda considerarse como justificado (razones axiológicas), para lo cual se precisa formular una serie de enunciados bien construidos (razones lingüísticas) cuyos contenidos se ajusten al ordenamiento jurídico (razones sistemáticas) y dan lugar a acciones (razones pragmáticas) que permitan alcanzar ese objetivo". ATIENZA (2019), p. 137.

${ }^{135}$ En el mes de julio del año 2010, tuvo lugar dicho debate ante las revelaciones de comunicaciones privadas que comprometían a funcionarios públicos, y daban cuenta de su presunta participación en actos de corrupción, también difundieron conversaciones comprometedoras de diversos líderes políticos en contextos electorales. La exposición de motivos de dicho proyecto da cuenta de casos mediáticos que motivaron el debate sobre la regulación del delito de interferencia telefónica, entre los que destacan los casos "Petroaudios", "Business Track" y la interceptación telefónica a la líder del Partido Popular Cristiano. Posteriormente, se modificó el referido tipo penal mediante el Decreto Legislativo $\mathrm{N}^{\circ}$ 1182, publicado el 27 de julio de 2015.
} 
establecidos en el artículo 162 del Código Penal peruano ${ }^{136}$. En su exposición de motivos, buscó precisar el contenido del interés público, conceptualizándolo como límite de la libertad de expresión frente a la protección del derecho a la privacidad e intimidad y secreto de las comunicaciones. ${ }^{137}$ Según esta propuesta, un contenido informativo será de interés público si versa, principalmente, sobre cuatro acciones que guardan una relación significativa con el rol del Estado y la protección de bienes públicos: la seguridad pública, protección de la salud, resguardo de la fe pública y la protección de los derechos constitucionales. ${ }^{138}$ Observamos una preocupación por definir el contenido del criterio del interés público a partir de su identificación con la acción del Estado. Asimismo, esta propuesta enfatizó la dimensión objetiva del interés público desde una descripción de los contenidos de la función pública, dejando en la dimensión subjetiva a los sujetos que se relacionan directa o indirectamente con dicha función. ${ }^{139}$

Consideramos acertado identificar como objeto de interés público a un conjunto amplio de asuntos en los que incide, mediata o inmediatamente, la actuación del Estado. Si bien esta es sólo una de sus dimensiones, refleja adecuadamente los presupuestos de los conceptos indeterminados al no crear una lista cerrada de contenidos. Esta aplicación práctica del interés público se centró en definir qué contenidos comunicativos son relevantes para la

136 Tipificado en el Código Penal, Título IV, Delitos contra la libertad, Capítulo IV, Violación del secreto de las comunicaciones, artículo 162, cuyo texto indica:

El que, indebidamente, interviene o interfiere o escucha una conversación telefónica o similar, será reprimido con pena privativa de libertad no menor de cinco ni mayor de diez años.

La pena privativa de libertad será no menor de diez ni mayor de quince años:

1. Cuando el agente tenga la condición de funcionario o servidor público, y se impondrá además la inhabilitación conforme al artículo $36^{\circ}$, incisos 1,2 y 4 .

2. Cuando el delito recaiga sobre información clasificada como secreta, reservada o confidencial de conformidad con la Ley $\mathrm{N}^{\circ}$ 27806, Ley de Transparencia y Acceso a la Información Pública.

3. Cuando el delito comprometa la defensa, seguridad o soberanía nacionales.

Si el agente comete el delito como integrante de una organización criminal, la pena se incrementa hasta en un tercio por encima del máximo legal previsto en los supuestos anteriores.

137 Proyecto de Ley No 4899/2010-PJ, p. 18 y s. En: https://bit.ly/2NDevbR, [visitado el 23.04.2017].

${ }^{138}$ En la exposición de motivos del Proyecto 2010-PJ se consideran materias de interés público: a) detener o denunciar la ejecución de un crimen o un grave mal comportamiento, b) proteger la salud o seguridad pública, c) prevenir al público de ser engañado por alguna declaración o acción de individuos u organizaciones, y d) proteger los derechos constitucionales. Este proyecto normativo también contó con aportes solicitados a la sociedad civil, entre ellos el del Instituto Peruano Prensa y Sociedad que elaboró una lista de contenidos comunicativos que calificarían como de interés público: a) asuntos o materias que inciden en el funcionamiento del Estado; b) materias que afectan derechos o intereses generales; c) aspectos relacionados con el ejercicio de las funciones públicas; d) asuntos que incidan o afecten a funcionarios, servidores públicos o personas que bajo cualquier modalidad laboran o prestan servicios para el Estado, a propósito de sus funciones; e) asuntos que incidan o afecten a personas que sin ser funcionarios o servidores públicos, ni prestar servicios o laborar para el Estado, desempeñan cargos, profesiones o actividades de interés o relevancia públicas, siempre que exista relación con tales cargos, profesiones o actividades; y f) asuntos sobre los que la sociedad en su conjunto tiene un legítimo interés en mantenerse informada, como por ejemplo, la comisión de delitos. INSTITUTO PERUANO PRENSA Y SOCIEDAD (2011), passim.

${ }^{139}$ La dimensión subjetiva del interés público coincide con el desarrollo doctrinal del concepto funcionario público. Al respecto, en la norma sustantiva peruana, la descripción de dicho sujeto se encuentra establecida en el artículo 425 del Código Penal, el cual establece que los siguientes sujetos son funcionarios públicos: 1. Los que se encuentran comprendidos en la carrera administrativa; 2. Quienes desempeñan cargos políticos o de confianza, incluso si emanan de elección popular; 3. Todo aquel que independientemente del régimen laboral en que se encuentre, mantiene vínculo laboral o contractual de cualquier naturaleza con entidades $u$ organismos del Estado y que en virtud de ello ejerce funciones en dichas entidades u organismos; 4. Los administradores y depositarios de caudales embargados o depositados por autoridad competente, aunque pertenezcan a particulares; 5. Los miembros de las Fuerzas Armadas y Policía Nacional; y 6. Los demás indicados por la Constitución Política y la ley. 


\section{Polít. Crim. Vol. 15, No 30 (Diciembre 2020), Art. 16, pp. 1009 - 1051 [http://politcrim.com/wp-content/uploads/2020/12/Vol15N30A16.pdf]}

discusión pública y, en consecuencia, ameritan ser protegidos en tanto ejercicios legítimos de la libertad de expresión.

Las propuestas de reforma, comprendidas entre los años 2006 y 2011, sostenían su argumentación sobre el criterio interés público de manera parcial, sin desplegar toda su eficacia justificante. En contraste, el Proyecto 2010-PJ, logró sistematizar mejor los alcances conceptuales de este criterio y aplicarlo en su fórmula legal. De haber seguido una argumentación similar, las fórmulas legislativas analizadas, habrían desarrollado argumentos más sólidos para trasladar los ilícitos contra el honor al ámbito civil, a partir de la inclusión de los presupuestos del principio democrático y de los derechos humanos. Esta deficiencia, no permitió justificar la distinción de los ejercicios legítimos de la libertad de expresión, que al versar sobre aspectos centrales para el debate público, se adscriben en un ámbito de protección reforzada.

En síntesis, los proyectos de ley analizados en el plano formal indican que el legislador peruano optó por una aplicación del interés público adscrita en la dimensión pública y republicana, salvo el proyecto 2018 que se aproximó a una opción liberal-republicana. Si bien advertimos mejoras significativas en la determinación conceptual del interés público, persiste la ambigüedad en su aplicación. Por ello, pese a los avances en relación a la precisión conceptual de su contenido como criterio normativo, su aplicación por parte del legislador peruano no cumple con las exigencias a nivel de técnica legislativa.

\subsubsection{Nivel material}

En relación con el nivel material, observamos que el interés público opera como núcleo argumental en las propuestas para la despenalización de los delitos contra el honor, elaboradas por el legislador peruano. Dicha aplicación parte de la inclusión de los estándares constitucionales y convencionales sobre la resolución de los conflictos iusfundamentales entre la libertad de expresión y el honor. También observamos la preferencia de argumentos de orden democrático desarrollados en las exposiciones de motivos, en especial de los Proyectos 2006, 2011 y 2018.

Dichas propuestas para la reforma de los tipos penales que protegen el honor, reconocen la importancia de los avances a nivel legislativo, jurisprudencial y doctrinal sobre los criterios para evaluar los discursos relativos a temas de interés público. En este sentido, los Proyectos 2006 y 2018 buscaron adecuar la legislación nacional a los estándares para la protección de la libertad de expresión e información. En particular, en el Proyecto 2018 se advierten los argumentos desarrollados en el caso Kimel vs. Argentina, en el que la Corte IDH señaló que la sanción penal resulta desproporcionada, dado que existen otros medios menos restrictivos para una efectiva defensa del derecho al honor. Según la tendencia advertida, toda una nueva iniciativa sobre los ilícitos contra el honor, deberá integrar los estándares para la protección de la libertad de expresión, en especial los alcances relativos al interés público desarrollados en el caso Álvarez vs. Venezuela, en el que la Corte IDH reiteró de manera categórica la necesidad de despenalizar los delitos contra el honor, máxime si los denunciantes son funcionarios públicos. ${ }^{140}$

Pese a que el Proyecto 2018 consigna un mecanismo previo al proceso judicial para la sanción de los ilícitos contra el honor, no desarrolló parámetros para abordar el problema de

140 CORTE INTERAMERICANA DE DERECHOS HUMANOS, Caso Álvarez Ramos vs.Venezuela. Excepción preliminar, Fondo, Reparaciones y Costas. Sentencia de 30 de agosto de 2019, párr. 76 y s. 
la determinación de la indemnización. Este es un punto que amerita mayor atención del legislador, quien deberá tomar en cuenta los alcances del caso Fontevecchia y D'Amico vs. Argentina. Caso en el que la Corte IDH advirtió que una orientación patrimonialista en la determinación de las indemnizaciones civiles, pueden tener un efecto inhibidor similar a las sanciones penales. Situación que sería más grave en el caso de los medios pequeños e independientes que no cuentan con los recursos de los grandes medios de comunicación. ${ }^{141}$

Los proyectos revisados también dan cuenta del reconocimiento del desarrollo jurisprudencial de la justicia constitucional y ordinaria, por parte del legislador peruano. ${ }^{142}$ Destaca por su importancia, la sistematización que el Tribunal Constitucional peruano realizó sobre la dimensión subjetiva del interés público, identificando tres supuestos en los que aplicaba la posición preferente de la libertad de expresión. ${ }^{143}$ Asimismo, en el año 2006, los jueces peruanos de la Corte Suprema elaboraron un precedente vinculante para la resolución de estos conflictos, denominado Acuerdo Plenario No 3-2006/CJ-116. ${ }^{144}$ Dicho precedente, estableció que el interés público, la veracidad de los hechos y la ausencia de expresiones injuriosas y vejatorias son características del ejercicio legítimo de la libertad de expresión. Sin embargo, limitó el tratamiento del interés público a la diferenciación entre la esfera pública y privada de las personas sin ahondar en sus dimensiones institucionales.

Salvo el Proyecto 2018, las demás iniciativas legislativas analizadas, no ofrecieron una respuesta suficiente para la protección del contenido protegido del derecho al honor a través de vías alternativas. Los problemas del ius puniendi que inciden en la libertad de expresión y el derecho al honor parten de la delimitación del contenido protegido de ambos derechos, de tal manera que las disposiciones para su protección superen las exigencias del principio de concordancia práctica, así como el fundamento de los principios del Estado democrático

\footnotetext{
${ }^{141}$ Este caso evidenció que pese a la despenalización de los delitos contra el honor en el ordenamiento penal argentino, funcionarios y personas públicas siguen formulando demandas en cuestiones de interés público. Por ello, constituye un segundo episodio en la discusión sobre los problemas relativos a la afectación patrimonial mediante el establecimiento de responsabilidades ulteriores. Esta discusión le dio la oportunidad a la Corte IDH para señalar que una indemnización desproporcionada puede ser un mecanismo sumamente lesivo y capaz de generar un efecto inhibidor equiparable a la sanción penal. CORTE INTERNAMERICANA, Caso Fontevecchia y D'Amico vs. Argentina, párr. 74.

${ }^{142}$ En el escenario previo al año 2000, la interpretación de la protección del honor era privilegiada por parte de los jueces peruanos, a partir de la aplicación de la teoría de la exclusión. Según dicha teoría, ante un conflicto entre el derecho a la libertad de expresión y el honor, los jueces optaban por este último. Ugaz señala que en aquel panorama aún no se habían incorporado la ponderación ni los lineamientos de la posición preferente para resolver los conflictos entre los referidos derechos fundamentales. Además de dicha falencia, la judicatura peruana optó preferentemente por valores como la moral, el respeto a la ley y la verdad, en lugar de una fundamentada defensa de la libertad de expresión. Este contexto interpretativo denota la ausencia de un espacio propicio para discutir decididamente sobre la posibilidad de una reforma de la protección penal del honor. Ugaz da cuenta de que durante el período de 1960 a 1999, la tendencia legislativa varió desde posturas muy restrictivas a la libertad de expresión a posiciones más liberales, lo cual incluía la libertad de agremiación para quienes ejercen el periodismo. UGAZ (1999), p. 103.

${ }^{143}$ En base a la proyección social de la persona, el Tribunal Constitucional del Perú desarrolló una tipología general de los sujetos comprendidos dentro del ámbito subjetivo del interés público: a) Personas cuya presencia social es gravitante por su activa participación en la vida política, económica y social. Están más expuestas al interés del público; b) Personas que gozan de gran popularidad pero no influyen en el curso de la sociedad; y c) Personas que realizan actividades públicas, pero no determinan la marcha de la sociedad. En este grupo estarían comprendidos los funcionarios públicos. Tribunal Constitucional del Perú, Caso Magaly Medina Vela y Ney Guerrero Orellana, Exp. No 06712-2005-HC, 17 de octubre de 2005, párr. 54.

${ }^{144}$ PLENO JURISDICCIONAL DE LAS SALAS PENALES PERMANENTE Y TRANSITORIAS DE LA CORTE SUPREMA DE JUSTICIA DE LA REPÚBLICA DEL PERÚ, Acuerdo Plenario N 3-2006/CJ-116, Delitos contra el honor personal y derecho constitucional a la libertad de expresión y de información, 13 de octubre del 2006.
} 
de derecho. ${ }^{145}$ Esta evaluación demuestra que una disposición normativa que no diferencia los discursos protegidos y los incluye prima facie en el ámbito de la tipicidad objetiva de los ilícitos contra el honor, no supera el test de necesidad y en consecuencia constituye una afectación desproporcionada del derecho a la libertad de expresión.

En materia de libertad de expresión, la actividad legislativa peruana presenta avances progresivos en la configuración de la dimensión material del interés público y su aplicación. En este sentido, advertimos la presencia de directrices basadas en dicho criterio para la resolución del conflicto iusfundamental entre el derecho a la libertad de expresión e información y el derecho al honor.

\subsubsection{Nivel pragmático}

A nivel pragmático, observamos que los Proyectos 2006 y 2010 produjeron mayores procesos deliberativos tanto en el Congreso como en la opinión pública. El Proyecto 2011 presenta una dinámica distinta ya que dicha fórmula legislativa fue incluida en el Proyecto de Reforma del Código Penal peruano. Por su parte, pese a los esfuerzos para dar a conocer y discutir los alcances de su propuesta, el procedimiento parlamentario del Proyecto 2018 se vio interrumpido por el cierre constitucional del Congreso. ${ }^{146}$ Sin embargo, el debate sobre la despenalización continúa en marcha, ya que en el mes de octubre del 2019, se anunció la preparación de una nueva iniciativa legislativa bajo los auspicios del Consejo de la Prensa Peruana, el Instituto Prensa y Sociedad y la Clínica Jurídica para la Libertad de Expresión de la Universidad del Pacífico, en el marco de la II Conferencia Anual sobre libertades informativas y transparencia. ${ }^{147}$

El Proyecto 2006, Proyecto 2011 y Proyecto 2018 denotan un reconocimiento de la importancia del rol de la prensa como mecanismo de control democrático y su incidencia en el debate público. Dados los términos del texto sustitutorio del Proyecto 2010, esta valoración resulta implícita. Este reconocimiento explícito e implícito en sede de la argumentación legislativa, se ha visto reforzado en el marco de los últimos acontecimientos de crisis institucional. Consideramos que estamos frente a una nueva etapa en el debate para la despenalización de los delitos contra el honor en Perú. En ella se advierte una significativa participación de organizaciones gremiales, académicas y de la sociedad civil, que coincide con el estado actual de la discusión sobre el nuevo Código Penal, donde todo debate sobre la despenalización de los delitos contra el honor no debe descuidar la promoción de mecanismos alternativos de protección y resarcimiento de las afectaciones al honor. Constatamos que la percepción ciudadana sobre el rol de la prensa para fiscalizar y denunciar casos de corrupción de gran envergadura ha mejorado significativamente. ${ }^{148}$ En este sentido,

\footnotetext{
145 "Mientras que la idoneidad y subsidiariedad necesitan de una clara lectura utilitarista, la proporcionalidad en sentido estricto constituye una parte del test eminentemente valorativa. Se trata fundamentalmente de equiparar los grados de restricción de derechos y libertades que comporta una medida con el grado de aumento de derechos y libertades que comporta". NIETO (2016), p. 437.

146 Decreto Supremo de cierre del congreso, publicado en la edición extraordinaria del 30 de setiembre del 2019. En: https://bit.ly/2oO5FPS [visitado el 10.10.2019].

${ }^{147}$ Evento realizado el 25 de octubre de 2019 en Lima. Contó con la presencia de representantes de dichas instituciones, así como del primer ministro en funciones, Vicente Zeballos, quien indicó que esta iniciativa se agendará para ser discutida en el marco de las próximas elecciones de representantes ante el Congreso Peruano, programadas para el 20 de enero de 2019. En: https://bit.ly/33fd61E [visitado el 29.10.2019].

${ }^{148}$ Según el informe de resultados del Estudio de opinión El Comercio - IPSOS, elaborado durante el mes de octubre de 2019. Dicho estudio describe que la percepción ciudadana valora positivamente el rol del periodismo de investigación para dejar en evidencia la trama de corrupción entre empresarios, políticos y
} 
la tarea argumentativa del legislador cuenta con mejores elementos de convicción provenientes de los operadores institucionales del Estado y de las organizaciones de la sociedad civil, para fortalecer, mantener y elevar su compromiso con la democracia y los derechos humanos.

\section{Conclusión}

El interés público es un concepto jurídico indeterminado que mantiene una noción dicotómica entre lo individual y lo colectivo. Procurar la definición del interés público en estos términos, contribuye a diseñar el ágora del debate a fin de evitar la frustración de proyectos de vida colectivos y de los proyectos de vida individuales. En su aplicación por parte del legislador peruano para despenalizar los delitos contra el honor cometidos a través de la prensa, se advierte que lo privado y lo público dejan de ser compartimentos estancos. También observamos que la tarea argumentativa del legislador peruano está orientada a extraer criterios del paradigma de Estado de Derecho moderno y conjugarlos con el paradigma liberal-republicano, en el que convergen la promoción de los espacios públicos de deliberación y la protección de los derechos individuales.

Dado que los proyectos de ley abordan el conflicto iusfundamental entre libertad de expresión y honor, aplicando el interés público a nivel normativo, paulatinamente fueron prestando mayor atención a las exigencias del principio de proporcionalidad. Si un discurso versa sobre temas relevantes para la sociedad, en especial aquellos que buscan evaluar la conducta de funcionarios públicos, el beneficio de la libertad de expresión es alto frente a la afectación del derecho de la personalidad. A partir de dicha operación, es posible señalar que los ejercicios legítimos de la libertad de expresión, que puedan afectar al honor, constituyen un conjunto de discursos que se adscriben en un ámbito de protección reforzada. Sin embargo, esta situación en abstracto no debe prescindir de los demás criterios para la evaluación de los actos comunicativos, desarrollados por los tribunales, en especial la exigencia de veracidad y la ausencia de expresiones vejatorias. De esta manera da un paso más respecto de la opción de política criminal configurada a partir de la posición preferente, asumida por los legisladores en una primera etapa. En la última iniciativa legislativa, que data del 2018, encontramos una argumentación más elaborada que incluye directrices para la aplicación del interés público bajo los deberes argumentativos de un legislador racional, afincado en la razón práctica y la ponderación.

La valoración positiva del rol que han desempeñado los medios de comunicación en Perú es un incentivo para motivar una nueva discusión sobre la despenalización de los delitos contra el honor, cometidos a través de la prensa. ${ }^{149}$ Independientemente de la dinámica política que tenga lugar en el nuevo parlamento, toda iniciativa relativa a esta temática, deberá integrar los estándares convencionales sobre la libertad de expresión y no descuidar la efectiva protección del derecho al honor, así como los aportes de otros procesos de reforma, en especial la experiencia argentina. En este sentido, se debe retomar la discusión tomando en cuenta la "explicación de sentido común de por qué las libertades básicas son inalienables podría decir, siguiendo una idea de Montesquieu, que las libertades básicas de cada ciudadano forman parte de la libertad pública, y por ello son, en un Estado constitucional de

magistrados, a propósito de casos como los de Odebrecht, Cuellos blancos del puerto, entre otros. En: https://bit.ly/2oJrj88 [visitado el 02.11.2019].

${ }^{149}$ PROÉTICA (2017), passim. 
Derecho, parte de la soberanía". ${ }^{150}$ Lograr la despenalización de los delitos contra el honor, cometidos a través de la prensa, puede ser un mecanismo de mejora de nuestra cultura de la legalidad y contribuir a la protección de los derechos humanos articulados a la institucionalización democrática del poder. ${ }^{151}$

${ }^{150}$ RAWLS (1996), p. 116.

${ }^{151}$ ALARCÓN (2007), p. 199 y ss. 


\section{Bibliografía citada}

ABAD, Samuel (2014): “La Defensoría del Pueblo. Hitos en su desarrollo institucional”, en: La fortaleza de la persuasión. Dieciocho años de la Defensoría del Pueblo. Edición conmemorativa de la Revista "Debate Defensorial" (Lima, Defensoría del Pueblo), pp. 119-151.

ALARCÓN, Gilmer (2007): Estado de Derecho, derechos humanos y democracia. Pautas para la racionalidad jurídico-política desde Elías Díaz (Madrid: Dykinson).

ALEXY, Robert (2007): Teoría de los derechos fundamentales (Trad. Carlos Bernal, Madrid, Centro de Estudios Políticos y Constitucionales).

ARIAS, Abel (2018): Clear and Present Danger test. La libertad de expresión en los límites de la democracia (Madrid, Marcial Pons).

ARISTÓTELES (2000): Política (Trad. Carlos García y Aurelio Pérez, Madrid, Alianza Editorial).

ATIENZA, Manuel (2019): Argumentación Legislativa (Buenos Aires, Astrea).

ATIENZA, Manuel; RUIZ MANERO, José (2000): Ilícitos atípicos (Madrid, Trotta).

AUDI, Robert (2004): Diccionario de Filosofía (Trad. Humberto Marraud, Madrid, AKAL).

BAJO, Miguel (1982): "Protección del honor y de la intimidad", en: COBO DEL ROSAL, Manuel; BAJO, Manuel Comentarios a la Legislación Penal. Tomo I (Madrid, Edersa).

BERDUGO, Ignacio (2000): Revision del contenido del bien juridico honor (Madrid, Fundación Alexander von Humbolt).

BERTONI, Eduardo (2000): "New York Times vs. Sullivan y la malicia real de la doctrina", en: MARIEZCURRENA, José, (Dir.), Estudios básicos de derechos humanos (San José: Instituto Interamericano de Derechos Humanos), pp. 121-150.

BOBBIO, Norberto (1998): Estado, gobierno y sociedad (México D.F., Fondo de Cultura Económica).

BOIX, Andrés; CARRILlO, Juan; GUICHOT, Emilio; DE LA SIERRA, Susana; VÁZQUEZ, Víctor (2013): Derecho de la comunicación (Madrid, Iustel).

BUCHANAN, James; MCCORMICK, Robert; TOLLISON, Robert (1984): El análisis económico de lo político (Trad. José Casas, Madrid, Instituto de Estudios Económicos).

BUOMPADRE, Jorge (2010): Delitos contra el honor (Buenos Aires, Astrea).

CALDERÓN, Andrés (2018): Tendencia en libertad de expresión en Perú (Buenos Aires: Centro de Estudios en Libertad de Expresión y Acceso a la Información \& Universidad de Palermo). Disponible en: https://bit.ly/2qmdQU4 [visitado el 23/03/2019].

CAPPELLETTI, Mauro (2010): ¿Jueces legisladores? (Trad. Laura Ochoa, Lima, Communitas).

CARMONA, Concepción (1996): Curso de Derecho Penal Español. Parte Especial (Madrid, Marcial Pons), t. I.

CARO, Dino (2002): Marco jurídico de la libertad de prensa en el Perú (Lima, Instituto Prensa y Sociedad).

CHARNEY, John (2016): "La tensión entre la libertad de emitir opinión y la de informar y la honra de las personas: importancia y límites de la exceptio veritatis", en: Revista de Derecho (Valdivia) $\left(\mathrm{n}^{\circ} 29\right)$, pp. 175-193. Dispoonible en: https://scielo.conicyt.cl/pdf/revider/v29n2/art08.pdf [visitado el 28/05/2017].

COMISIÓN INTERAMERICANA DE DERECHOS HUMANOS (1986): "Exigibilidad del derecho de rectificación o repsuesta" Opinión Consultiva OC-7/86, solicitada por el gobierno de Costa Rica, 29 de agosto, San José, 1986. 
COMISIÓN INTERAMERICANA DE DERECHOS HUMANOS. Informe No 22/94. Caso 11.012. Argentina. Solución Amistosa. 20 de septiembre de 1994.

COMITÉ PARA LA PROTECCIÓN DE LOS PERIODISTAS - CPJ (2015): Los críticos no son delincuentes. Estudio comparativo de leyes penales de difamación en las Américas. Disponible en: https://bit.ly/2TrhIgV [visitado el 20/09/2017].

CONSTANT, Benjamin (2002): De la libertad de los antiguos comparada con la de los modernos, Conferencia pronunciada en el Ateneo de París en 1819, Trad. María Sánchez (Valladolid, Universidad de Valladolid).

COVARRUBIAS, Ignacio (2015): "La vida privada de los funcionarios públicos frente a dos derechos: el acceso a la información pública y la libertad de expresión. (Algunos criterios empleados en la jurisprudencia chilena y comparada y su importancia relativa)", en: Revista Ius et Praxis ( $\left.{ }^{\circ} 21\right)$, pp. 217-270.

DE PABLO, Alejandro (2018): La protección penal del honor y el conflicto con las libertades comunicativas. Modelos del Common Law, continental europeo y del Convenio Europeo de DD.HH, Buenos Aires: BdeF.

DE PABLO, Alejandro (2014): Los delitos contra el honor en el Derecho Penal español y en el derecho comparado. Tesis para optar al grado de Doctor, Universidad de Valladolid, Departamento de Derecho Penal e Historia y Teoría del Derecho.

DEFENSORÍA DEL PUEBLO (2000), Situación de la Libertad de Expresión en el Perú, Lima: Defensoría del Pueblo.

DÍEZ, José (2003): "El Derecho penal simbólico y los efectos de la pena", en: Crítica y justificación del Derecho penal en el cambio de siglo (Cuenca: Ediciones de la Universidad de Castilla - La Mancha).

DWORKIN, Ronald (1984): Los derechos en serio, Trad. GUASTAVINO, Martha, Barcelona: Ariel.

DWORKIN, Ronald (1986): El imperio de la justicia (Trad. Claudia Ferrari, Barcelona: Gedisa).

DWORKIN, Ronald (2019) El Derecho de las libertades (Trad. Matías Parmigiani, Lima: Palestra).

FERRAJOLI, Luigi (2004): “¿Democracia sin Estado?,” en: Cauces. Expresión de los estudiantes de la Facultad de Derechos de la UNAM ( $\left.{ }^{\circ} 11\right)$, pp. 8-17, en: https://bit.ly/2r0e3JU [visitado el 25.06.2017].

FISS, Owen (2004): Libertad de expresión y estructura social (Trad. Jorge Malem, México D.F.: Fontamara).

FISS, Owen (1999): La ironía de la libertad de expresión (Trad. Víctor Ferreres y Jorge Malen, Barcelona, Gedisa).

GARCÍA DE ENTERRÍA, Eduardo (1974): La lucha contra las inmunidades del Poder (Madrid, Civitas).

GARCÍA, Domingo; EGUIGUREN, Francisco (2018): “La evolución políticoconstitucional del Perú 1976-2005”, en: Estudios Constitucionales (nº 6), pp. 371398.

GARZÓN, Ernesto (2006): Lo íntimo, lo privado y lo público. En Tolerancia, dignidad y democracia (Lima: Fondo Editorial de la Universidad Inca Garcilazo de la Vega), pp. 61-103.

GONZÁLES, Felipe (1997): Las Acciones de Interés Público: Argentina, Chile, Colombia y Perú (Santiago de Chile, Ediciones de la Universidad Diego Portales).

GONZÁLEZ, Felipe; VIVEROS, Felipe (2000): Igualdad, Libertad de Expresión e Interés Público. Cuadernos de Análisis Jurídico No 10 (Santiago, Serie de Publicaciones Especiales de la Universidad Diego Portales). 
HABERMAS, Jürgen (1981): Historia y crítica de la opinión pública (Trad. Antonio Doménech, Antonio, Barcelona, Gustavo Gili).

HERNÁNDEZ, María (1997): Mecanismos de tutela de los intereses difusos y colectivos. (México D.F.: Instituto de investigaciones juridicas de la UNAM).

ITURRALDE, Manuel (2011): Libertad de expresión y litigio de alto impacto (Bogotá: Universidad de los Andes).

LA RUE, Frank (2012): "Informe del Relator Especial de las Naciones Unidas sobre la promoción y protección del derecho a la libertad de opinión y expresión”, Consejo de Derechos Humanos de las Naciones Unidas,

LANDA, César (2010): "Estudio introductorio", en: TRIBE, Laurence; DORF, Michael, Interpretando la Constitución (Lima, Palestra), pp. 7-33.

LANDA, César (2018): La constitucionalización del Derecho. El caso del Perú (Lima, Palestra).

LAPORTA, Francisco (2002): "La creacion judicial y el concepto de Derecho Implícito", en: Revista Jurídica de la Universidad Autónoma de Madrid (nº 6), pp. 133-152.

LAPORTA, Francisco (1993): Entre el Derecho y la moral (México, Fontamara).

LAURENZO, Patricia (2002): Los delitos contra el honor (Valencia, Tirant lo Blanch).

LIFANTE, Isabel (2002): "Dos conceptos de discrecionalidad jurídica", en: Doxa. Cuadernos de Filosofía del Derecho (nº 25), pp. 413-479.

LÓPEZ, Nicolás (2010): "El interés público: entre la ideología y el derecho", en: Anales de la Cátedra Francisco Suárez (nº 44), pp. 123-148.

LOVERA, Domingo (2006): "El interés público como estándar. Libertad de expresión y vida privada", en: GONZÁLEZ, Felipe (edit.) Libertad de Expresión en Chile (Santiago, Universidad Diego Portales).

MAIZA, Carlos (1995): "La definición del concepto del honor. Su entidad como objeto de investigación histórica", en: Espacio, Tiempo y Forma, Serie IV, Historia Moderna, $\left(\mathrm{N}^{\mathrm{o}} 8\right)$, pp. 191-209.

MARCIANI, Betzabé (2004): El derecho a la libertad de expresión y la tesis de los derechos preferentes (Lima: Palestra).

MEJÍA, Ricardo (2016): "Deontología del periodista”, en: IBERICO, Luis (Ed.): La palabra firme (Lima: Fondo Editorial del Congreso).

MENDOZA, Mijail (2007): Conflictos entre derechos fundamentales. Expresión, información y honor (Lima, Palestra).

MILL, John Stuart (2013): Sobre la libertad (Trad. Pablo de Azcárate, Madrid: Alianza Editorial).

MIR PUIG, Santiago (2011): Derecho Penal. Parte General, 9ª (Buenos Aires: BdeF, 2011).

MORESO, José (2002): "En defensa del positivismo jurídico inclusivo", en: NAVARRO y REDONDO (Coord.) La relevancia del Derecho (Barcelona, Gedisa), pp. 93-116.

MUÑOZ, Francisco (2001): Derecho penal, Parte Especial, 13 ${ }^{\mathrm{a}}$ ed. (Valencia: Tirant Le Blanch).

NIETO, Adán; MUÑOZ, Marta; BECERRA, José (2016): Hacia una evaluación racional de las leyes penales (Madrid, Marcial Pons), pp. 407-443.

NINO, Carlos (2003): Fundamentos de Derecho Constitucional. Análisis filosófico, jurídico y politológico de la práctica constitucional (Buenos Aires, Astrea).

NINO, Carlos (2003): La constitucion de la democracia deliberativa (Barcelona, Gedisa)

NOGUEIRA, Humberto (2004): "Pautas para superar las tensiones entre los derechos a la libertad de opinión e información y los derechos a la honra y la vida privada", en: Revista de Derecho de la Universidad Austral de Chile (n 17), pp. 139-160.

PEÑA, Alfonso (2015): Los delitos contra el honor. Conflicto con el derecho a la información y la libertad de expresión (Lima, Instituto Pacífico). 
PEÑA, Marisol; ROSALES, Cecilia (2001): “El interés público en el constitucionalismo postmoderno", en: Revista de Derecho de la Universidad Católica de Valparaíso, (nº 22), pp. 483-502.

PERELMAN, Chaim; OLBRECHTS-TYTECA, L. Tratado de la argumentación (Trad. Julia Sevilla, Madrid, Gredos).

PLENO JURISDICCIONAL DE LAS SALAS PENALES PERMANENTE $Y$ TRANSITORIAS DE LA CORTE SUPREMA DE JUSTICIA DE LA REPÚBLICA DEL PERÚ, Acuerdo Plenario N³-2006/CJ-116, Delitos contra el honor personal y derecho constitucional a la libertad de expresión y de información, 13 de octubre del 2006.

PONCE, Zoila; GARCÍA, Luis (2019): "Perú 2018: La precariedad política en tiempos de Lava Jato", en: Revista de Ciencia Política (n 39), pp. 341-365. Disponible en: https://bit.ly/2swL5p5 [visitado el 15.10.2019].

QUERALT, Joan (1996): Derecho Penal, Parte Especial (Barcelona, Bosch).

QUINTANO, Antonio (1972): Tratado de la Parte especial del Derecho Penal II, $2^{\mathrm{a}}$ ed., (Madrid: Editorial Revista de Derecho Privado), Tomo I.

RAWLS, John (1996): Sobre las libertades (Trad. Jorge Vigil, Barcelona, Paidós).

REBOLLO, Rafael (1992): Aproximación a la jurisprudencia constitucional: Libertad de expresión e información y sus límites penales (Barcelona: P.P.U.).

RELATORÍA, ESPECIAL PARA LA LIBERTAD DE EXPRESIÓN DE LA COMISIÓN INTERAMERICANA DE DERECHOS HUMANOS (2009): Marco Jurídico Interamericano sobre el Derecho a la Libertad de Expresión, Costa Rica: Organización de los Estados Americanos.

REVENGA, Miguel (2008): La libertad de expresión y sus límites (Lima, Grijley).

RIVERO, Juan (2008): Tutela jurídica del honor: reflexiones y contrapuntos (San José: Editorial Jurídica Continental).

RÓDENAS, Ángeles (2012): Los intersticios del derecho. Indeterminación, valdez y positivismo jurídico (Madrid, Marcial Pons).

ROXIN, Claus (1997): Derecho Penal. Parte General, Tomo I. Fundamentos. La estructura de la teoría del delito (Trad. Diego Luzón; Miguel García; Javier Remesal, Madrid, Civitas).

SANDAY, Peggy (2013): "Un modelo para la etnografía de interés público: la conjunción de teoría, práctica, acción y cambio en un mundo globalizado", en: Revista de Antropología Social ( $\mathrm{n}^{\circ}$ 22), pp. 199-232. Disponible en: https://bit.ly/34umH5v [visitado el 15.09.2019].

SANTANA, María (2000): La protección penal de los bienes jurídicos colectivos (Madrid: Dykinson).

SCHWABE, Jürgen (2009): Jurisprudencia del Tribunal Constitucional Federal Alemán (México D.F., Konrad Adenauer Stiftung).

UGAZ, José (2016): “Entre el derecho a la libertad de expresión y el derecho al honor", en: IBERICO, Luis (Ed.), Palabra libre. El derecho a la información, medios de comunicación y autoregulación (Lima: Fondo editorial del Congreso del Perú).

UGAZ, José (1999): Prensa juzgada. Treinta años de juicios a periodistas peruanos (19691999) (Lima, IPYS-UPC).

VALLESPIN, Fernando (1998): "Estudio Introductorio: Una disputa de familia: el debate Rawls - Habermas", en: HABERMAS, Jürgen; RAWLS, John, Debate sobre el liberalismo político (Trad. Gerard Vilar, Barcelona, Paidos - I.C.E. de la Universidad Autónoma de Barcelona), pp. 9-28. 
VÁSQUEZ, Pepe (2016): "Los delitos contra el honor y la tutela del derecho a la vida privada de las personas", Tesis para obtener el grado de Maestría en Derecho Penal y Ciencias Criminológicas de la Universidad Nacional de Trujillo.

VILLAVICENCIO, Felipe (2017): Derecho Penal. Parte Especial.Vol. I (Lima, Grijley).

VISINTINI, Giovanna (2015): "Indemnización del daño moral". En: SOTO, Carlos; TRAZEGNIES, Fernando; PANTALEÓN, Fernando; LORENZETTI, Ricardo (Edits.), Daño extrapatrimonial: Daño moral; Daño a la prensa (Lima: JURIVEC), pp. 34-54. 